\title{
Diverse conditions support near-zero growth in yeast: Implications for the study of cell lifespan
}

\author{
Jordan Gulli ${ }^{1}$, Emily Cook ${ }^{1}$, Eugene Kroll ${ }^{1}$, Adam Rosebrock ${ }^{2,3}$, Amy Caudy ${ }^{2}$ and Frank Rosenzweig ${ }^{1, *}$ \\ ${ }^{1}$ School of Biological Sciences, Georgia Institute of Technology, Atlanta, GA 30332. \\ 2 Donnelly Centre for Cellular and Biological Research and Department of Molecular Genetics, University of Toronto, Toronto, \\ Ontario, Canada. \\ 3 Present address: Stony Brook School of Medicine, Stony Brook University, Stony Brook, NY 11794. \\ * Corresponding Author: \\ Frank Rosenzweig, School of Biological Sciences, 310 Ferst Drive. Atlanta, GA 30332-0230. Ph: 404.385.4458; FAX: 404.894.0519; \\ E-mail: frank.rosenzweig@biology.gatech.edu
}

\begin{abstract}
Baker's yeast has a finite lifespan and ages in two ways: a mother cell can only divide so many times (its replicative lifespan), and a non-dividing cell can only live so long (its chronological lifespan). Wild and laboratory yeast strains exhibit natural variation for each type of lifespan, and the genetic basis for this variation has been generalized to other eukaryotes, including metazoans. To date, yeast chronological lifespan has chiefly been studied in relation to the rate and mode of functional decline among non-dividing cells in nutrient-depleted batch culture. However, this culture method does not accurately capture two major classes of long-lived metazoan cells: cells that are terminally differentiated and metabolically active for periods that approximate animal lifespan (e.g. cardiac myocytes), and cells that are pluripotent and metabolically quiescent (e.g. stem cells). Here, we consider alternative ways of cultivating Saccharomyces cerevisiae so that these different metabolic states can be explored in non-dividing cells: (i) yeast cultured as giant colonies on semi-solid agar, (ii) yeast cultured in retentostats and provided sufficient nutrients to meet minimal energy requirements, and (iii) yeast encapsulated in a semisolid matrix and fed ad libitum in bioreactors. We review the physiology of yeast cultured under each of these conditions, and explore their potential to provide unique insights into determinants of chronological lifespan in the cells of higher eukaryotes.
\end{abstract}

doi: 10.15698/mic2019.09.690 Received originally: 06.05.2019; in revised form: 08.07.2019, Accepted 09.07.2019, Published 20.08.2019.

Keywords: baker's yeast, chronological lifespan (CLS), near-zero growth, starvation, giant yeast colonies, retentostats, encapsulation, immobilized cell reactors.
Abbreviations:
CFU - colony forming unit,
CLS - chronological lifespan,
$C R$ - caloric restriction,
$I C R-I m m o b i l i z e d$ cell reactor,
$P C D$ - programmed cell death,
$Q$ - quiescent,
QS-quorum sensing,
$R L S$ - replicative lifespan,
$T C A$ - tricarboxylic acid,
TOR-target of rapamycin.

\section{INTRODUCTION}

Aging, or the progressive loss of function over time, is a hallmark feature of all living cells, including 'simple' organisms such as baker's yeast [1]. More than half a century ago, Mortimer and Johnson [2] reported that individual yeast cells are mortal and have a limited capacity for cell division. Subsequent demographic analyses showed that mortality increased exponentially as yeast populations underwent successive rounds of replication in batch culture. Replicatively aging yeast undergo characteristic morphological and biochemical changes that include increasing cell size, accumulation of bud scars, slowing of the cell cycle, and accumulation of extrachromosomal rDNA circles [3-5]. Genetic variation is associated with strain-specific differences in the rate of func- tional decline, manifest as strikingly different mean replicative lifespans (RLS) among wild and laboratory yeasts [6, 7]. Yeast also age chronologically, as evidenced by the decline and eventual death of a non-dividing cell over its chronological lifespan (CLS). Because microbes cannot divide in the absence of essential nutrients, yeast CLS has most frequently been studied in relation to the survival of free-floating (planktonic) cells in nutrient-depleted liquid culture [8-10]. Such cells enter $\mathrm{G}_{0}$ arrest and initially undergo metabolic and structural changes that include accumulation of storage carbohydrate, cell wall thickening, an overall decline in protein synthesis, an increase in stress tolerance, and a shift to respiratory metabolism $[8,11]$. Viability among starving planktonic yeast cells diminishes over time, as does their replica- 
tive capacity, suggesting that RLS and CLS may be linked mechanistically [11]. Caloric restriction (CR) during the time non-dividing yeast age delays the progressive reduction in RLS [12-14]. Indeed, among chronologically old cells, those that have the lowest mitochondrial membrane potential (reducing ATP production) [15] also have the longest subsequent RLS; thus, mitochondrial function may constitute a causal link between CLS and RLS [16]. Further evidence for this link is provided by rho(0) cells, which experience both lower mitochondrial membrane potential and longer RLS than do rho(+) cells [17]. Strain-specific variation in CLS exists among wild yeast isolates, assayed as survivorship of starving planktonic cells [18], and the genetics underlying this variation has been generalized to other eukaryotes, including animals [19].

\section{CHRONOLOGICAL AGING IN STARVED PLANKTONIC CULTURES}

Screens for CLS mutants in starved yeast cultures have uncovered genes involved in stress-resistance and nutrientsignaling pathways [20-23]. Some of these pathways, like the target-of-rapamycin (TOR)-pathway, are highly conserved among eukaryotes and have been implicated in aging processes in worms, flies and mammals [24-27]. However, starvation poorly mimics the physiology of major classes of metazoan cells. Terminally differentiated cells such as cardiac myocytes and neurons consume a large proportion of the organism's energy and are typically well nourished [28]. Although growth-arrested, such cells remain metabolically active and perform large amounts of work with minimal functional decline, often for decades in higher animals [29]. Starvation also poorly mimics the physiology of mitotically quiescent cells, such as hematopoietic stem cells and myosatellite cells that, respectively, can quickly be recruited to form blood cells or to regenerate injured skeletal muscle. Satellite cells are "Iying low but ready for action," being not only mitotically but also metabolically quiescent, having few mitochondria, and deriving most of their maintenance energy requirements from anaerobic (i.e. fermentative) metabolism [30]. Hematopoietic stem cells also appear to derive most of their maintenance energy requirements from fermentative metabolism, and indeed, the switch to mitochondrial respiration appears to be necessary for stem cell differentiation [31, 32].

The starving yeast aging paradigm, where lifespan is measured in nutrient-depleted planktonic cells, therefore falls short as a model to study the physiology of cells that are either growth-arrested but metabolically active, or growth-arrested but metabolically quiescent, i.e. those cells that are on the front lines and those that are held in reserve. To make up for this shortfall, alternative yeast culture conditions are needed in which mitotically-arrested cells can be studied under circumstances that range from caloric excess to $C R$. Here, we consider alternatives to the starving yeast paradigm (Figure 1A) where near-zero growth rates can be achieved by other means. These include aging yeast cultured on solid medium (Figure 1B), in retentostats (Figure 1C), or as encapsulated cells in contin- uously-fed bioreactors (Figure 1D). With these culture methods at their disposal, yeast researchers can investigate determinants of chronological lifespan in a variety of contexts: closed systems (Figure 1A, B), and open systems (Figure 1C, D), matrix-free (Figure $1 \mathrm{~A}, \mathrm{C}$ ), and matrixassociated (Figure 1B, D), nutrient-limited (Figure 1A, B, C), and nutrient-replete (Figure 1D). Below we consider how these different contexts lead to physiological states that better approximate metabolism in non-dividing animal cells than do starving planktonic yeast.

\section{CHRONOLOGICAL AGING IN YEAST COLONIES General considerations}

Yeast CLS has been studied in the context of colonies growing on the surface of nutrient agar $[33,34]$, typically under aerobic conditions on complex media $[35,36]$ for periods ranging from 20-130+ days. Unlike cells cultured in ideallymixed liquid media, giant colonies (created by spotting a cell suspension onto GMA [37]) are in a spatially-structured environment, where they experience gradients of nutrients, waste products, signaling molecules, and gases [38]. These gradients, in turn, influence how cells stratify in colonies and age within those strata, much like a morphogenetic field in early embryological development [39]. By ten days postinoculation, colonies have differentiated vertically into two cell types, only one of which divides [40]. In this respect, the colony resembles a multicellular organism, in that it is largely clonal and consists of a mixed population of dividing and non-dividing cells.

Cells in a colony display slower growth, and higher viability than aging planktonic cells

The various gradients experienced by cells in colonies [41] create selective pressures not experienced by planktonic cells in liquid culture. Cells on agar and cells in liquid culture behave similarly just after inoculation [36]. But soon thereafter colonies undergo a longer period of slow growth than do planktonic cells ( $>8$ days on solid medium vs. 40 hours in liquid) [42]. Diffusion provides cells growing on solid agar with a slow, steady nutrient supply [40], making it possible for the population to gradually expand for up to 32 days [35] However, not every cell in a colony can divide: the number of colony-forming units (CFUs) recovered after dilution and plating on fresh agar asymptotes after 18 days. And by 90 days as much as $25 \%$ of a colony consists of cells that are alive but unable to reproduce on rich medium, a likely result of chronic nutrient deprivation, much like oligotrophic environments in nature host large numbers of viable but nonculturable cells [43].

Patterns of reproduction and survivorship in giant colonies contrast sharply with those patterns in planktonic culture, where biomass accumulation typically ceases 3 days post-inoculation [44]. After 10 days in synthetic dextrose complete (SDC; $2 \%$ dextrose) medium, only $5 \%$ of starving planktonic yeast may be viable [45]. By contrast, after 10 days on GM agar (1\% yeast extract, $3 \%$ glycerol, $1.5 \%$ agar), yeast in giant colonies are $90 \%$ viable and do not fall to $5 \%$ until after 135 days. In both instances, viability was estimat- 
A. Planktonic
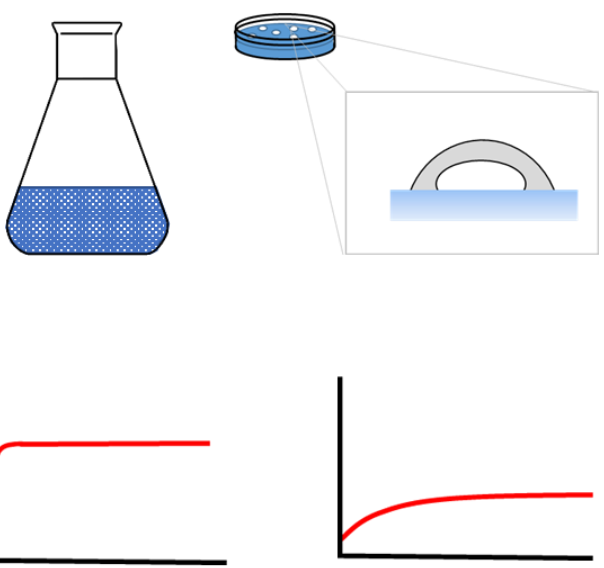

Time

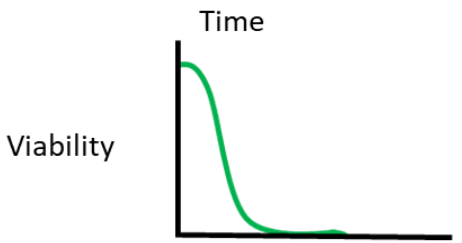

Time

\section{Retentostat}
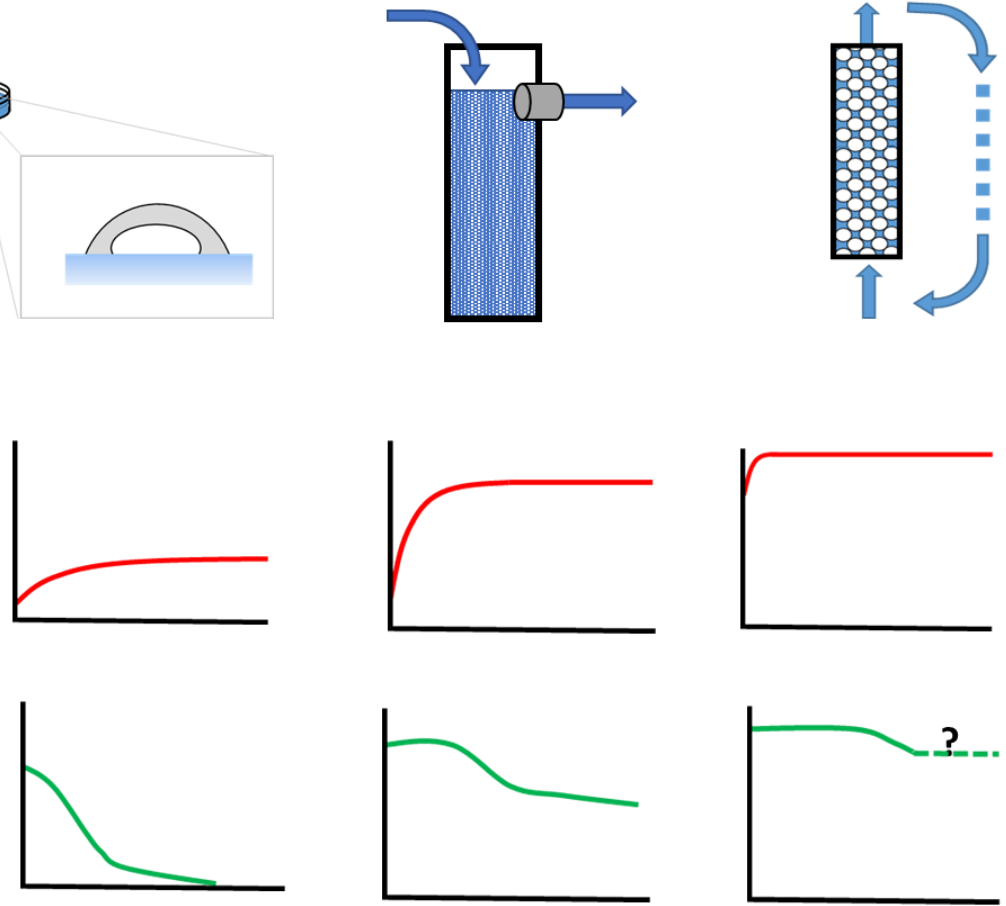

D. ENCAPSULATED CELL REACTOR

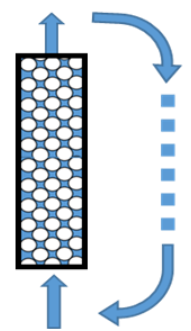

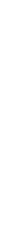
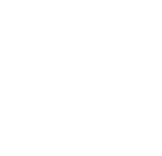

FIGURE 1: Chronological lifespan of non-dividing yeast has been studied using multiple culture methods. (A) planktonic cultures, (B) colonies on plates, (C) retentostats, and (D) encapsulated cell reactors, each of which presents a different time-dependent profile of biomass accumulation and cell viability.

ed as the proportion of total direct counts recovered as CFUs [35]. At all time-points measured, yeast in colonies exhibit greater viability than their isogenic counterparts in planktonic culture, even among strains that differ in $\operatorname{CLS}[35,46,47]$. This observation has led Palkova and colleagues to speculate that prolonged slow growth of yeast cells in colonies is analogous in some ways to CR [35], a factor shown to increase lifespan in all species examined to date $[12,14,48,49]$.

\section{Yeast in aging colonies become physiologically- differentiated}

In an aging colony, subpopulations of cells differentiate in both vertical (Figure 2A; upper vs. lower) and horizontal (Figure 2B; center vs. margin) dimensions, with subpopulations aging in different ways and at different rates [50,51]. Following 10 days of incubation, spatially-segregated cell types can be distinguished from one another and from their progenitors with respect to morphology, nutrient utilization, and stress resistance. Cellular differentiation within giant colonies has been linked to production of volatile ammonia, which is believed to contribute to, or even drive, formation of stratified layers within a colony. The process has been described in detail [52-55], and recently reviewed by Vachova and Palkova $[50,51]$.

\section{Vertical stratification of $U$ and $L$ cells in aging yeast colonies}

Along the vertical axis, cells in giant aging colonies stratify into upper (U) cells and lower (L) cells. U cells typically exhibit multiple small vacuoles and swollen mitochondria having few cristae [38]. Further characteristics of $U$ cells include glycogen accumulation, lipid droplet formation, and low mitochondrial transmembrane potential, as indicated by staining with $\mathrm{DiOC}_{6}$, a mitochondrial dye. In contrast with $U$ cells, $L$ cells contain numerous mitochondria with well-developed cristae, and exhibit a high transmembrane potential by $\mathrm{DiOC}_{6}$ staining, $[36,56]$. Accordingly, $\mathrm{L}$ cells produce 3 -fold more reactive oxygen species than $U$ cells, and exhibit higher respiratory capacity [56].

Paradoxically, L cells display attributes reminiscent of both starved and exponentially-growing planktonic cells. Like starved planktonic cells, $L$ cells are actively respiring: glucose-repressible genes are de-repressed, including those in mitochondrial biogenesis, oxidative phosphorylation, and nonfermentable carbon source utilization (e.g. HAP5, USV1, RTG1) [56, 57]. However, like exponentialphase planktonic cells, $\mathrm{L}$ cells are sensitive to heat shock, cell wall dissolution by zymolyase, and exhibit no TOR activity [56]. Further, recent studies on finely-dissected giant colonies indicate that among L-cells, upper and lower $\mathrm{L}$ 
subpopulations can be discriminated on the basis of their distinctive patterns of gene expression [57].

Physiological differences between $U$ and $L$ cells lead to differences in stress resistance and CLS within an aging colony. For example, at day 50 only $10 \%$ of $L$ cells are still viable, compared to $50 \%$ of $U$ cells [50]. Higher viability among $U$ cells is correlated with activation of regulatory pathways like TOR, typical of cells growing under nutrientrich conditions [58]. But $U$ cells also exhibit features typical of yeast under nutrient limitation, such as activation of the general amino acid control pathway [50]. This unusual physiology suggests active consumption of some nutrients, but limitation by others, and contrasts with the physiology of $L$ cells, which upregulate genes involved in nonfermentable carbon source utilization rather than TOR.

\section{Cell stratification benefits some cell types at the expense} of others, contributing to colony longevity

Autophagy is important for survival in $\mathrm{U}$, but not $\mathrm{L}$, cells. Colonies derived from strains having defects in autophagy $(\operatorname{atg} 1 \Delta, \operatorname{atg} 12 \Delta, \operatorname{atg} 5 \Delta, \operatorname{atg} 8 \Delta)$ exhibit reduced $U$ cell viability, particularly in older colonies, but have no effect on $L$ cell viability. This observation raises the possibility that $L$ cells may provide an energy source for $U$ cells. Indeed, $L$ cells activate degradative pathways related to proteasomal and vacuolar function, and upregulate expression of genes involved in glucose export [50]. Defects in these genes diminish $U$ cell viability, providing evidence that $U$ cells depend on $L$ cell degradation and $L$ cell glucose export for their survival. Ninhydrin staining indicates that $L$ cells also release amino acids, with their total intracellular amino acid content decreasing by $23 \%$ between days 15 and 20 . Finally, $\mathrm{L}$ cells are zymolyase-sensitive and upregulate cell wall glucanases (Scw11p, Dse4p, Egt2p), suggesting they may release cell wall constituents that serve as carbon sources for $U$ cells. The consumption of $L$ cells by $U$ cells may benefit the colony as a whole, assuring not only its survival, but also its dispersal. All things being equal, cells on a colony's exterior are more likely to be dispersed either by water or by insects than cells in its interior. However, exterior cells are distant from diffusible nutrients in the colony substratum. L cells may thus engage in a form of altruism that benefits their kin, as $U$ and $L$ cells are essentially clones of one another [59].

Horizontally-stratified cells may also engage in autophagy. Cells in the colony center begin to differentiate from those on the colony margins around the same time that $U$ and $L$ cells differentiate (Figure 2). Superoxide concentrations increase in center cells, even as they simultaneously decrease in margin cells $[54,60]$. As a result, center cells undergo accelerated programmed cell death (PCD) relative to margin cells. In contrast with either accidental or regulated cell lysis, PCD results in the release of lytic enzymes that damage or destroy healthy neighboring cells [50, 51]. Thus, similar to $U$ cells receiving nourishment from $L$ cells, center cells' PCD may contribute to overall colony survival by providing nutrients that nourish margin cells. This idea is supported by the observation that removing center cells from a differentiated colony leads to diminished growth at the colony margin [46]. While cells in a giant yeast colony undergo apoptosis similar to cells undergoing PCD in a multicellular organism, the process does not recruit Mca1p or Aif1 $p$, and must therefore be regulated differently than in metazoans [36].

\section{Giant colonies as a model to study aging and cancer}

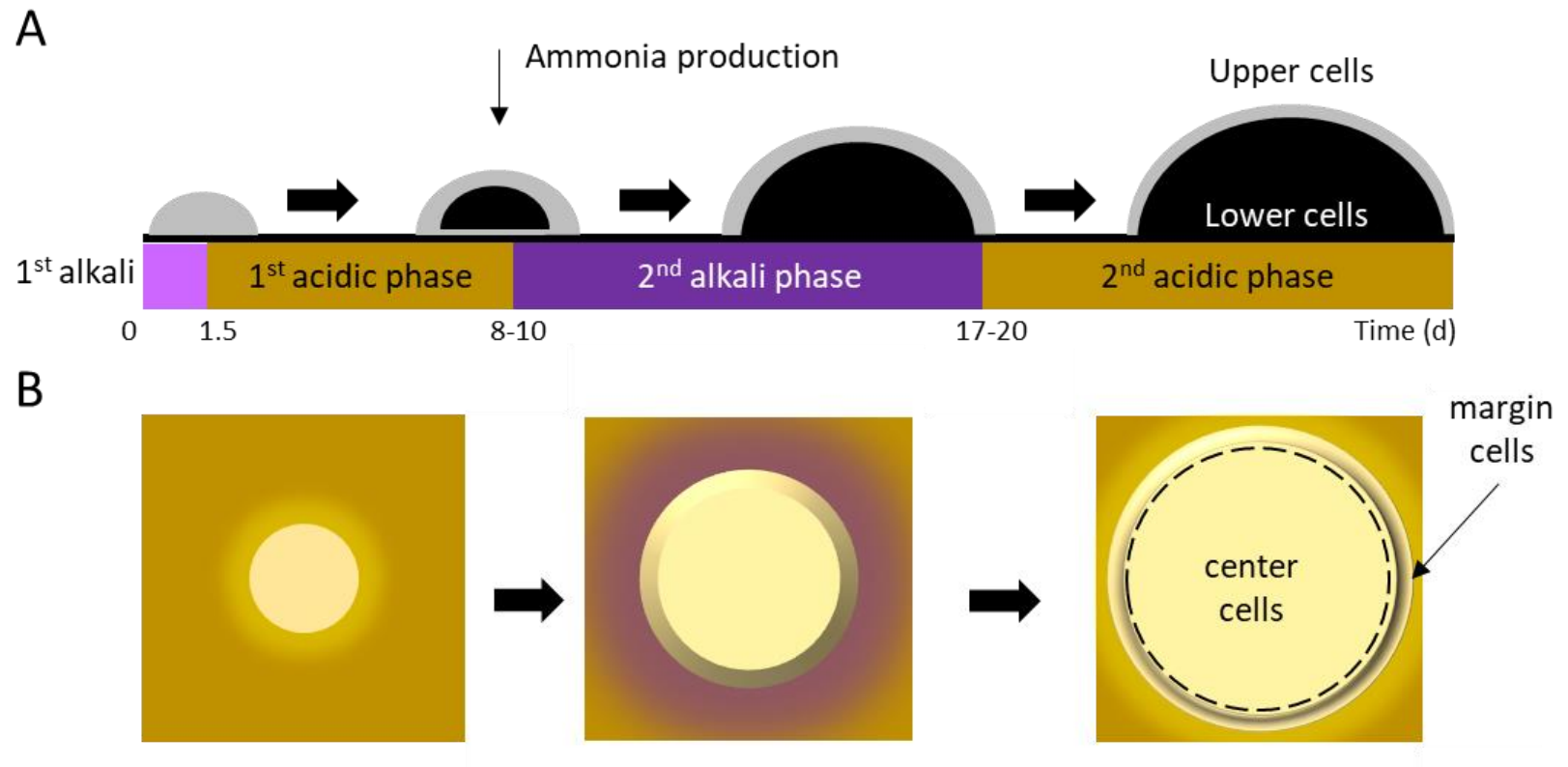

FIGURE 2: Yeast colonies transition through alkali ( $\mathrm{pH} \sim 6.8$ ) and acidic (pH $\sim 5.2$ ) phases, causing the area around a colony to change in color from yellow to purple and back again on agar containing Bromocresol purple. The pH changes contribute to cellular differentiation in both the vertical (A) and horizontal (B) dimensions. Gray indicates healthy, dividing cells and black indicates non-dividing cells. 
Yeast in a colony ages differently than starving, planktonic yeast. As planktonic cells age, they increasingly express stress-defense genes (SOD1, SOD2, CTT1) [61, 62]. But as colonies age, expression of stress-related genes, including those encoding oxidative stress defense enzymes, decreases, at least among certain cell types $[52,56]$. Also, while SOD1 is known to be essential for yeast longevity in liquid cultures $[63,64]$, it does not appear to be essential for colony survival and longevity $[60,61]$. Cells in colonies are exposed to gradients of nutrients, waste products and gases whose complex spatial and temporal dynamics result in a mosaic of physiologically differentiated cell types that open up the possibility for myriad cell-cell interactions. Consequently, yeast growing as colonies on agar more closely resemble the tissues of multicellular organisms than do planktonic yeast in liquid culture [61]. Yeast growing as colonies might also be used to model mammalian cancer cells as both maintain high glycolytic flux; by contrast, starving planktonic cells may be a more a suitable model for tumor necrosis $[56,65]$.

$U$ and $L$ cells can be easily isolated [36] and their physiological differences exploited to model different types of metazoan cells. Whereas $L$ cells could be used to model healthy mammalian tissue [56], $U$ cells exhibit certain attributes of tumors, notably progressive changes in mitochondrial morphology such as swelling and loss of cristae [66], ammonia induced autophagy [67], lowered respiratory capacity [68], and the activation of amino acid biosynthesis and TOR $[56,69]$. Further, nutrient and waste product flow between $U$ and $L$ cells are reminiscent of how the Cori and the glutamine-ammonium cycles interplay between healthy and tumor cells [51,56]. Still, like starving planktonic yeast in liquid media, a yeast colony growing on agar is a closed system having limited material exchange with the external environment, save for gases or volatiles such as alcohols. In this respect, both techniques imperfectly model metazoan cells, which are open systems.

\section{CHRONOLOGICAL AGING IN CONTINUOUS CULTURE: THE RETENTOSTAT \\ General considerations}

In yeast, cell reproduction is usually coupled with metabolism [70]. Regardless of whether cultured as planktonic cells in liquid media, or as colonies on agar, yeast eventually ceases to divide because it lacks essential nutrients. By contrast, many animal cell types undergo $G_{0}$ arrest in the presence of excess nutrients [71], and then begin to age chronologically. Another way to better model mammalian CLS with yeast is to culture it in a retentostat (Figure 1C), a continuous-flow system whose operational principles were first described by Herbert [72]. This apparatus is a variant of the more familiar chemostat [73-77] where balanced growth of planktonic cells is achieved by continuous flow of a growth limiting-nutrient through a bioreactor. At steady state, microbial specific growth rate, $\mu$, is equal to the dilution rate, $D$, defined as the outflow flow rate of spent medium ( $F_{\text {out }}$ in $\mathrm{L} / \mathrm{h}$ ) over the liquid volume of culture (VL) in the bioreactor. Depending on species, strain and type of limiting nutrient, chemostats are typically run at $0.4 \mathrm{~h}^{-1}>\mathrm{D}>0.03 \mathrm{~h}^{-1}$. Similar to chemostat, in a retentostat all nutrients save one, an energy source, are present in non-limiting concentrations. However, unlike a chemostat, cells in a retentostat are prevented from leaving the reactor in the spent medium stream. Thus, cells can be cultured to high cell densities (Figure 1C; $\sim 15 \mathrm{~g}$ biomass per L) [78] at near-zero growth rates ( $\mathrm{D}<$ $\left.0.001 \mathrm{~h}^{-1}\right)$. Continuous retentostat cultures maintain homeostasis between cells' rate of substrate consumption and their maintenance energy requirements. Like a chemostat, and indeed like a metazoan with a circulatory system, the retentostat is an open system, continuously exchanging nutrients and wastes with its external environment.

\section{Retentostat growth and viability}

Boender et al. 2009 were among the first to study $S$. cerevisiae in retentostats. Under anaerobic conditions, in a chemostat running at $D=0.025 \mathrm{~h}^{-1}$, cells satisfy their maintenance energy requirements, estimated to be $0.50 \mathrm{mmol}$ of glucose per gram of biomass per hour. Starting at $D=0.025 \mathrm{~h}^{-1}$, cell outflow can be blocked by filtration, transforming the chemostat into a retentostat. After 7 days, growth rate in the retentostat decreased to $<0.004 \mathrm{~h}^{-1}$, and after 22 days growth rate fell to $<0.001 \mathrm{~h}^{-1}$, corresponding to a doubling time of 27 days. Over 22 days of retentostat cultivation, cell viability fell from $91 \pm 8 \%$ to $79 \pm 6 \%$. Glycogen content more than doubled over this interval, from $4.3 \pm 0.8 \%$ in chemostat cultures at $D=0.025 \mathrm{~h}^{-1}$ to $9.1 \pm 0.6 \%$ in retentostat cultures at $22 \mathrm{~d}\left(\mathrm{D}<0.001 \mathrm{~h}^{-1}\right)$; trehalose content did not change $(1.0 \pm 0.4 \%)$. Retentostats therefore open up possibilities for studying cell physiology under conditions of severe CR and very low growth rate.

\section{Transcriptomics}

Boender and colleagues have carried out genome-wide expression studies of retentostat yeast, comparing its profile to those of faster-growing chemostat yeast $\left(D=0.025 \mathrm{~h}^{-1}\right)$ [79]. Beginning with a culture growth rate of $0.025 \mathrm{~h}^{-1}$ at day 0 , growth rate in the retentostat decreased after 2 days to $0.0084 \mathrm{~h}^{-1}$, then leveled off at $0.00063 \mathrm{~h}^{-1}$ after 22 days [79]. At 22 days $15 \%$ of cells were budded, typical for nongrowing S. cerevisiae [80], and viability was estimated to be $\sim 80 \%$ [79]. Relative to chemostat-grown cells $\left(D=0.025 \mathrm{~h}^{-1}\right)$, transcript levels in retentostat-grown cells $\left(D=0.00063 \mathrm{~h}^{-1}\right)$ were increased for 615 genes, and decreased for 241 genes ( $q$-value $<0.000188$ by $K$-means clustering). Transcript levels of many house-keeping genes (e.g. ACT1, PDA1, ALG9, TAF10, TFC1, UBC6) did not differ between these two cultivation regimes [79], indicating sustained metabolic activity. Among genes whose transcript levels did increase relative to chemostat-grown cells, those related to mitochondrial function were strikingly over-represented, notably 32 of 76 genes encoding mitochondrial ribosomal proteins, as well as genes that encode respiratory chain sub-units (e.g. ATP4, ATP7, ATP15, COX5B, COX8, COX9, COX11, COQ5, COQ9, SOC1, SCO2), protein processing (IMP1, IMP2, SOM1), and mitochondrial membrane transport (TIM17, TOM6) [79]. Upregulation of mitochondrial functions may therefore represent specific cellular adaptations to near-zero growth unrelated to either oxygen tension or glucose concentration [79]. Of 
genes whose transcript levels decreased, those in lipid and sterol metabolism were over-represented, though this could be an artifact of amending anaerobic cultures with ergosterol and the oleate ester Tween-80.

Transcript levels were elevated for multiple genes involved in repairing damaged DNA or protein (SIR2, RAD10, $R A D 24, R A D 27)$. Upregulation of SIR2 and its homologs may enhance genome stability in retentostat-grown cells relative to cells in chemostats, as SIR2 deletion is known to increase genome instability [81]. Diminished expression of SIR2 homologs reduces longevity in planktonically-grown yeast [82, 83] and may impact human aging as well [84], making the behavior of these genes of particular interest.

\section{Proteomics}

Calorically restricted retentostat yeast is metabolically active, and its gene expression program suggests it may be protected against DNA and/or protein damage, even after 22 days [85]. Given these observations, it is not surprising that the yeast proteome also changes upon induction of near-zero growth under CR [86]. Of 3,813 proteins detected in a study comparing retentostat cells to faster-growing cells $(D=0.025$ $\mathrm{h}^{-1}$ ), the levels of 252 proteins significantly increased while an equal number decreased, altogether $13 \%$ of the detectable proteome. By comparison, $31 \%$ of the proteome is expressed differently between exponential and stationary phase batch cultures [87]. Among proteins whose expression increased relative to faster growing cells were those in the oxidative branch of the tricarboxylic acid (TCA) and glyoxylate cycles as well as 5 of 6 proteins in the succinate dehydrogenase complex (Sdh1p, Sdh2p, Sdh3p, Sdh1bp, and Shh3p) [88]; these proteins are typically not expressed under anaerobic conditions [89]. Among proteins whose expression decreased in retentostats were $4 / 17$ proteins involved in ergosterol biosynthesis, and 8/14 proteins forming the Like-Sm ribonucleoprotein core [86], which is thought to activate mRNA decapping [90].

Interestingly, the transcriptome and proteome datasets correlated poorly, with only 146 of 504 proteins changing with the same sign and magnitude as their associated transcripts [86]. Of the 146 proteins whose changes were consistent with changes in their transcript levels, two-thirds were higher in retentostats, notably 28 of 110 of mitochondrial proteins and 11 of 53 proteins in oxidative phosphorylation. Poor correlation between transcript and protein levels has been previously observed in stationary phase cultures in S. cerevisiae and in Schizosaccharomyces pombe [91, 92]. This finding may stem from half-life differences between proteins $\left(0.5 \mathrm{~h}<\mathrm{t}_{1 / 2}<20 \mathrm{~h}\right)$ [93] and mRNAs ( $3 \mathrm{~min}<\mathrm{t}_{1 / 2}<8 \mathrm{~h}$ ) [94]. These differences may be exaggerated in cells under nutrient limitation as more energy is required to synthesize proteins $(1957 \mathrm{mmol}$ ATP/100 g formed biomass) than mRNAs (201 mmol ATP/100 $\mathrm{g}$ formed biomass) [95]. Transcriptomic and as well as proteomic datasets do indicate tight regulation over proteins and transcripts related to $\mathrm{O}_{2}$ consumption, suggesting that this is of special importance to calorically restricted cells.

\section{Starvation vs. caloric restriction}

A key distinction between cells in retentostats and cells in nutrient-depleted planktonic cultures is that the former are not starving. Unrelieved, starvation inexorably leads to cellular deterioration [96-99]. By contrast, retentostat cells are calorically restricted, a condition operationally defined as cells being fed one third to one half that of cells fed $a d$ libitum, without inducing malnutrition or starvation $[13,48$, $86,100]$. In a retentostat cells are supplied with enough carbon and energy for cell maintenance and survival, but not enough for reproduction. But while they exhibit some features of starving cells, like increased heat shock resistance and expression of certain quiescence-related genes [79], calorically-restricted retentostat yeast are more metabolically active and have higher viability [14].

Starvation and CR are physiologically different states; this can be illustrated by inducing starvation in a retentostat via elimination of the sole carbon source. Calorically restricted retentostat yeast turn over ATP at a rate of 1 $\mathrm{mmol}$ per gram of biomass per hour [14]. By contrast, within 24 hours of starvation induction, ATP turnover rate falls to less than $2 \%$ of this value $(0.013 \mathrm{mmol}$ per gram of biomass per hour). Twenty-one days after starvation induction, ATP turnover rate drops even further, to $0.0002 \mathrm{mmol}$ per gram of biomass per hour.

Compared to cells in chemostats $\left(D \cong 0.025 \mathrm{~h}^{-1}\right)$, retentostat yeast shows decreased expression of genes required for protein synthesis $[79,86]$. Still, there is evidence for protein synthesis [85] despite its energetic cost [101]. Active protein synthesis and recycling among such cells explains their high levels of metabolic activity $(>70 \%)$ and viability $(60 \%)$, even in 22 -day old cultures $[85,86]$. Although they are severely nutrient-limited, retentostat yeast is sensitive to further dietary restriction: starvation results in the immediate downregulation of a large fraction of the protein synthetic machinery $(25 \%)[14,85]$. Twenty-six hours after starvation induction retentostat cells exhibit high levels of apoptosis (43\%) and greatly diminished viability (15\%).

To compare the transcriptome of starving cells to that of $C R$ cells whose maintenance energy requirements are being met, Boender et al. cultured yeast in retentostats with and without glucose. 549 genes were differentially expressed [14]. Levels of 140 transcripts were upregulated in carbon starved cells, including genes encoding dehydrogenases (e.g. $M D H 3, D L D 1, B D H 1, B D H 2, S D H 1$ ) involved in the glyoxylate, Cori, and TCA cycles, among others, as well as genes whose products are required for growth on nonfermentable carbon sources (e.g. HBT1, FMP45, SPG4, $S P G 1)$. Transcript levels for the remainder were downregulated in starved cells, including 109 genes in protein synthesis, as well as 30 genes involved in amino acid biosynthesis. Starvation and CR are thus distinct physiological states that can be expected to have very different impacts on cell lifespan.

Yeast retentostats as a model for the study of chronological aging 
Calorically restricted cells in retentostats can be used to gain fresh insight into factors governing lifespan in nondividing metazoan cells. Unlike starving planktonic cells, retentostat cells do not differentiate into quiescent and non-quiescent cell types [102]; instead, cells remain in an extended $\mathrm{G}_{1}$ phase [103]. With its active metabolism and near-zero growth rate, retentostat yeast is well-suited to model non-proliferating metazoan cells that are poised in $\mathrm{G}_{1}$ and supplied with their maintenance energy requirements [104], including reserve (as opposed to active) epithelial stem cells [105] and cervical reserve cells [106]. Retentostat yeast could also be used to study disease, e.g., retentostat-cultured rim15 15 yeast exhibits phenotypes reminiscent of cancer cells, notably heat shock sensitivity [107] and unresponsiveness to anti-growth signals [108]. Still, retentostat cells are nutrient-limited, whereas many somatic metazoan cells are not. And even retentostat enthusiasts attest to the challenges of its set-up and operation [78, 109-111].

\section{CHRONOLOGICAL AGING IN CONTINUOUSLY-FED IMMOBILIZED CELL REACTORS \\ General considerations}

Microbial, plant and metazoan cells can be immobilized in a variety of matrices, ranging from naturally-derived hydrogels such as agarose, alginate, chitosan, collagen, fibrin, gelatin, and hyaluronic acid [112] to synthetic hydrated polymers and inorganic substrates, such as silica gels, sintered glass, and ceramic beads [113]. In naturally-derived hydrogels, microbial encapsulation (a type of immobilization) typically results in spherical beads whose diameter can be fixed in the range of micro- to millimeters. These beads, and the cells they contain (Figure 3 ), can then be placed into immobilized cell reactors (ICRs; Figure 1D) and operated either as closed, batch-culture systems or as open, continuously-fed systems. The latter, which include stirred tank, packed and fixed-bed reactors [114], allows for continuous exchange of nutrients and waste between cells in their extracellular matrix and the liquid medium flowing through the reactor.

\section{Industrial applications}

ICRs have chiefly been studied with an eye towards their use in biotechnology. There, they offer three advantages over conventional planktonic batch culture: (i) high productivity in terms of yield per cell, (ii) increased stability during the production cycle, and (iii) prolonged dry storage times. These advantages, reported by many [115-120], arise from the fact that gel-encapsulated cells reproduce slowly, if at all, and therefore divert little substrate to new biomass, which allows for more efficient substrate utilization [121]. Longer production cycles can be attributed to encapsulated cells' greater resistance to acids [122, 123], organic solvents [124, 125], ethanol [126], osmotic stress, and thermal stress [127, 128]. Greater stress resistance may also be associated with altered composition and organization of both the cell wall and plasma membrane [129], as well as with mechanical protection against shear provided by the encapsulating matrix [130]. In yeast, increased dry storage time without substantial loss in viability is consistent with the immobilized cells' higher content of storage and structural polysaccharides [116, 131, 132].

\section{Potential for cell-cell interactions among encapsulated yeast}

Yeast cells immobilized in alginate 'beads' cease to divide after reaching a certain density, which accounts for their high fermentative capacity, and likely also their exceptional longevity and resistance to stress. It is tempting to speculate that the physical proximity of such cells in a semi-solid matrix (Figure 3), coupled with their entry into a $\mathrm{G}_{0}$-like state, confers upon them certain features of tissue levelorganization, including social interactions. Strains isolated from the wild exhibit a variety of behaviors that have the potential to facilitate cell-cell interactions; these include floc [133] and flor formation [134], adhesion [135-137], as well as a kind of primitive multicellularity [138-141]. Yeast can also form biofilms [135], which in effect causes cells to become immobilized in a matrix of their own manufacture. Many of these behaviors are correlated with increased resistance to ethanol stress $[142,143]$, enhanced thermotolerance and osmotolerance [144], and improved survivorship in the presence of inhibitory compounds [145]. Similarly, encapsulated yeast become stress tolerant, though particular resistance profiles are specific to the type of encapsulating matrix $[127,146]$.
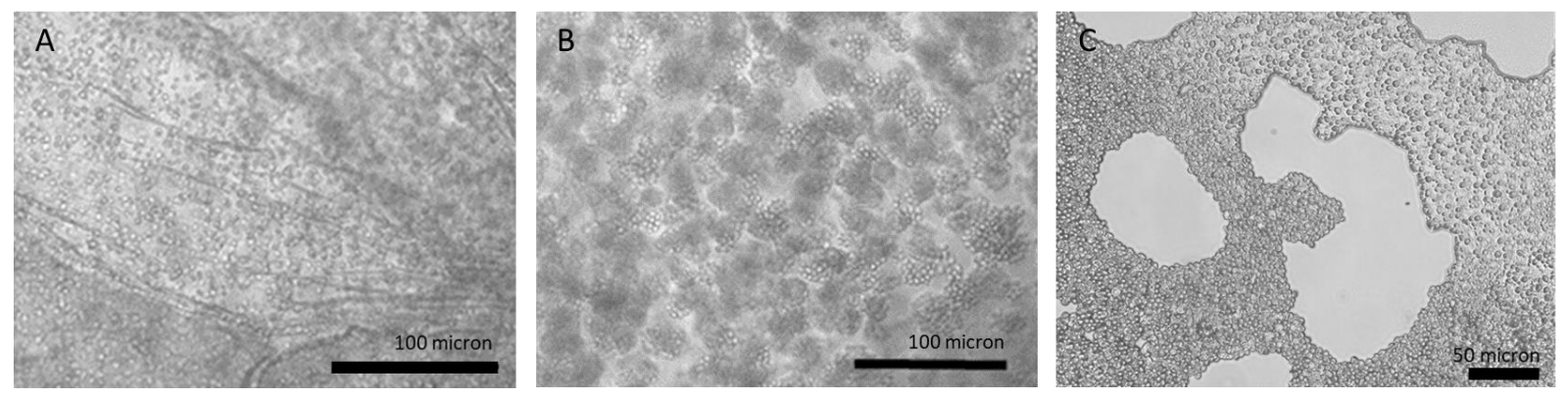

FIGURE 3: Yeast microcolonies form in alginate-encapsulated beads packed in immobilized cell reactors. Immediately after gelation (A), the interior of bead consists of primarily single, unbudded cells evenly dispersed throughout alginate matrix, but by 3 days in ICR (B), cells have evenly dispersed in clonal clusters of 4 or more cells. After 14 days in ICR (C), cells are tightly packed, occupying majority of matrix material. Hollow chambers are dispersed throughout beads, presumably formed by $\mathrm{CO}_{2}$ generation. 
Social behavior in immobilized yeast appears to rely on intercellular signaling or quorum sensing (QS), which can be mediated by peptide pheromones [147] or by various organic compounds (alcohols, aldehydes and volatiles) [148]. An important criterion for a QS mediator is that it needs to reach a certain concentration before eliciting a concerted response which goes beyond that needed to metabolize or detoxify the compound [149]. One example of collective behavior in yeast is the onset of glycolytic oscillations relying on autocatalytic regulation of phosphofructokinase [150]. Glycolytic oscillations with a period of 25-32 s become synchronized in yeast cells depending on their concentration in alginate [151] and chitosan [152] beads, and are probably induced by locally high concentrations of acetaldehyde. We hypothesize that encapsulated yeast engage in social interactions and signal to each other in ways reminiscent of metazoan somatic cells [153]. Whether the $\mathrm{G}_{0}$-like state observed in such yeast is induced by QS, by mechanical forces like "self-jamming" [154], or is maintained by combination of chemical and mechanical factors remains to be explored.

\section{Physiology and transcriptomics}

Nagarajan et al. 2014 validated that reproduction is uncoupled from metabolism in continuously-fed, alginate encapsulated yeast, described one of its genetic determinants, and provided evidence that such cells are exceptionally long-lived [132]. The authors also showed that continuously-fed immobilized yeast exhibit a stable pattern of gene expression that is distinct from both growing and starving planktonic cells, consisting of an increased expression of genes in cell wall remodeling, glycolysis, and stress resistance, and an decreased expression of genes in the TCA cycle and cell cycle regulation (Figure $\mathbf{4}$ and discussion below) [132]. These highly metabolically active cells achieved near-zero growth rates within $72 \mathrm{~h}$ postencapsulation, and maintained this state for nearly 3 weeks, during which time upwards of $80 \%$ of cells remained virgin daughters [132]. Together, these attributes open up the possibility for developing a model to study cellular senescence and CLS in non-dividing eukaryotic cells, both in the absence and in the presence of CR.

Kruckeberg et al. developed methods to perform, for the first time, global analysis of gene expression in immobilized microbial cells [155]. Affymetrix GeneChips were used to profile the transcriptome of encapsulated yeast cells, compared to that of planktonic yeast grown either in glucose-limited chemostats or in glucose batch culture (midlog and early stationary phase). Data from immobilized cultures revealed a pattern of gene expression that differed from planktonic cells, and remained stable over $>2$ weeks of continuous culture. Fewer than 100 genes changed by more than two-fold and none changed in sign. Transcript abundance conspicuously increased for multiple glycolytic genes (e.g., HXK2, PFK2 and PGK1) and decreased for genes in the TCA cycle (e.g., CIT2,3 and ACO1,2) and in the cell cycle (e.g., CLN1 and CDC28) [156]. These data provide yet another line of evidence that ICR yeast is metabolically active, but growth-arrested.
Additional features of this dataset included increased transcription of genes that act in cell wall remodeling. RPI1 up-regulation in encapsulated cells is especially noteworthy. Rpi1 acts as an antagonist to the RAS-cAMP pathway, and prepares yeast for entry into stationary phase by inducing transcription of genes whose products fortify the cell wall [157]. Like non-reproductive quiescent cells and spores, and like cells in the retentostat, immobilized yeast is highly heat-shock and zymolyase-resistant. However, unlike such cells, immobilized yeast fed ad libitum sustains a high rate of metabolism. In experiments described by Nagarajan et al. (2014), medium was continuously circulated within the bioreactor, exchanging the void volume once per minute. Every $48 \mathrm{~h}$ the feed reservoir was replaced with fresh SDC medium containing a five-fold excess of all micronutrients amended with $10 \%$ glucose as sole carbon source. Over 9 such cycles glucose was continuously fermented at near-theoretical yield with an undiminished rate of conversion.

Transcript levels of stress response regulators MSN4 and RIM15 were significantly increased in immobilized, but not in planktonic, cells. RIM15 plays a role in cell cycle arrest, as multiple nutrient-sensing pathways converge on Rim15p [158]. RIM15 has also been reported to promote chronological longevity in both starving planktonic yeast $[100,159]$ and yeast in retentostats [160]. Based on these converging lines of evidence, Nagarajan et al. hypothesized that this master regulator played a central role in uncoupling metabolism from reproduction in immobilized yeast. Flow cytometry of DNA content revealed that unlike wild type cells, rim $15 \Delta$ cells exhibit a pronounced $G_{2}$ peak at later time points in ICR culture, indicating that they continue to divide. After 5 days of continuous culture viability of immobilized rim $15 \Delta$ yeast fell to $25 \%$, compared to $>90 \%$ in immobilized wild type cells. RIM15 thus helps to mediate cell cycle arrest and stress resistance in the ICR model, and may contribute to ICR cells' extraordinary chronological longevity. The discovery that this remarkable physiological state is under genetic control opens the door to screening large numbers of barcoded knock-outs, a procedure likely to reveal new classes of longevity genes that alter lifespan in the absence of severe CR.

Of particular interest, but as yet not studied, is $X B P 1$, which encodes a global regulator of entry into quiescent (Q) phase [161]. In this context, Xbp1 represses hundreds of genes following exhaustion of glucose, including $\mathrm{G}_{1} \mathrm{cy}$ clins such as CLN3 [162]. The Rad9/Rad53 checkpoint may act in the same pathway, protecting cells from replicative stress in cultures lacking glucose [163]. Similar to Q cells, recent data show that encapsulated cells are exceptionally resistant to starvation. Indeed, survivorship of starved encapsulated cells is several -fold higher than starved planktonic cells (Cook and Kroll, unpublished data). The XBP1/G cyclin pathway, in conjunction with starvation/stress signal transduction and replicative checkpoints, needs to be studied in encapsulated cells that cease to divide, similar to $Q$ cells, but do so in the presence of nutrients, unlike $Q$ cells. 


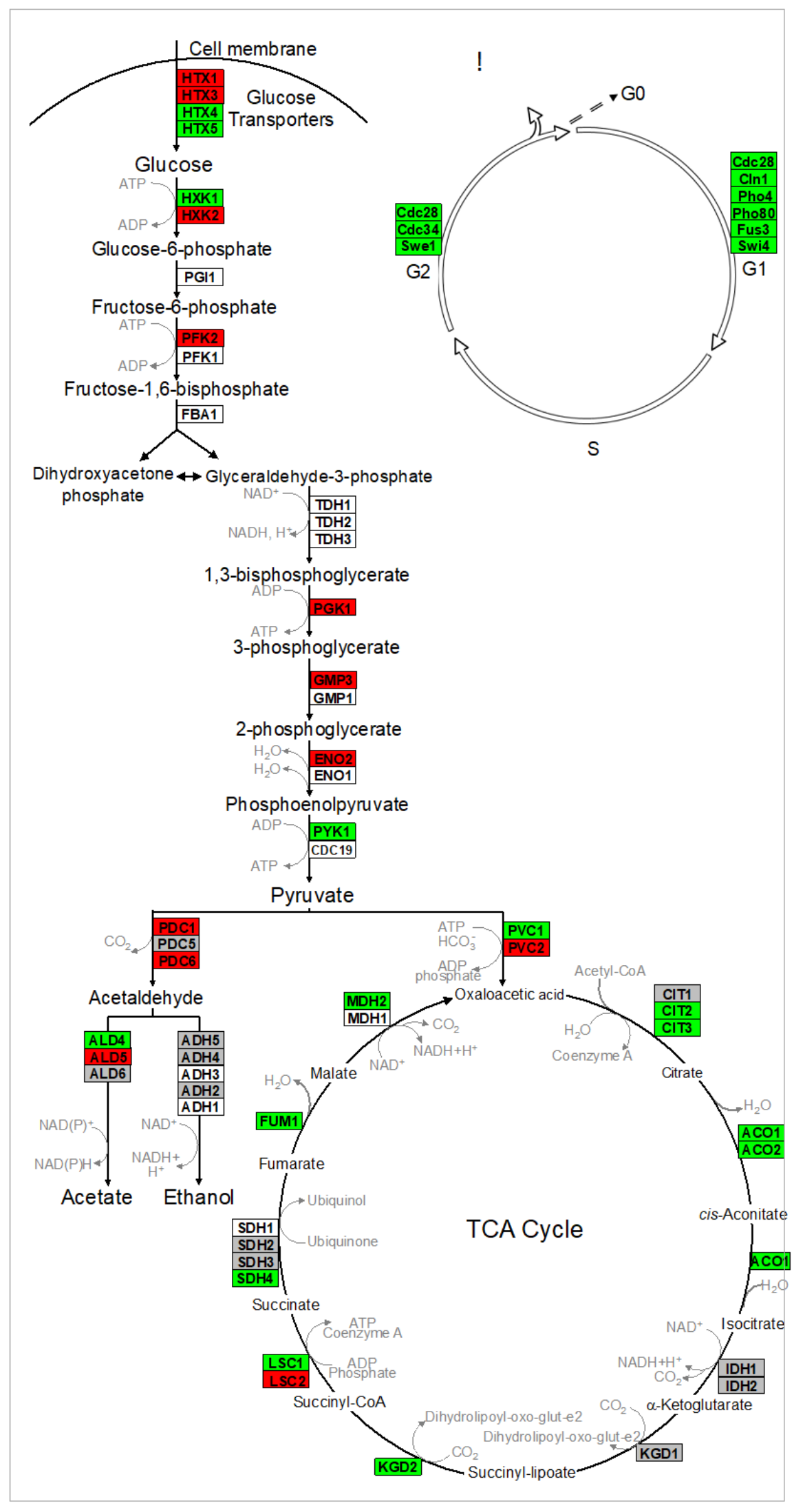

FIGURE 4: Alginate-encapsulated yeast cultured in continuously-fed bioreactors exhibit a stable pattern of gene expression in (A) intermediary metabolism, and (B) cell cycle where transcript abundance of glycolytic genes is increased, and that of TCA cycle and cell cycle genes is decreased. Red indicates genes where expression was at least two-fold greater in encapsulated cells than in planktonic cells over the course of 2 weeks culture. Green indicates instances where those values were at least two-fold less. Gray indicates no significant difference in sign or magnitude between planktonic and encapsulated cells (image adopted from Nagarajan et al. 2014 [132]). 
This may further connect well-fed encapsulated yeast cells to somatic cells in metazoans that also adjust their cell cycle machinery to uncouple reproduction from metabolism [164].

\section{Proteomics and metabolomics}

Consistent with conclusions drawn from transcriptomics, a proteomic study of alginate-chitosan-encapsulated yeast in comparison with isogenic planktonic cells uncovered widespread changes in gene expression [146]. Encapsulated and planktonic cells were grown for $25 \mathrm{~h}$ in synthetic medium amended with $5 \%$ glucose, and the relative levels of 842 proteins were analyzed by mass spectrometry and $2 \mathrm{D}$ gel electrophoresis. A significant increase in central metabolic proteins was observed among immobilized cells, especially glutamine metabolism and fermentation, including proteins normally under glucose inhibition, such as highaffinity hexose transporters (Hxt6, Hxt7) and hexose kinases (Hxk, Glk1). This study also noted marked decreases in the level of proteins involved in protein synthesis and RNA transport. Interestingly, some stress response proteins were upregulated (Ssb2, Hsp12, Hsp26, Hsp78 and Hsp104), while others were downregulated (Ras2, Sod1, and many others) [146].

Metabolite levels also differ between encapsulated and planktonic culture conditions. When encapsulated cells are fed ad libitum, as in Nagarajan et al. [132], levels of succinate, citramalate, and citrate increase by several-fold relative to planktonic cells as determined by liquid chromatography mass-spectrometry (Figure 5). By contrast, while levels of fumarate and malate are similar across all conditions, alpha-ketoglutarate levels decrease many-fold in encapsulated cells. Some of these metabolomic changes could not easily have been predicted from the transcriptomic data. For example, expression data reveal no significant differences between planktonic and encapsulated cells in the transcript levels of $I D H 1 / 2$ or $K G D 1$, yet their respective substrate and product, alpha-ketoglutarate, is at very low levels in ICR. It is possible that such discrepancies can be explained, for example, by diminished expression of key enzymes upstream of a metabolite pool. In the case of alpha-ketoglutarate, expression of both citrate synthase (CIT2/CIT3) and aconitase (ACO1/ACO2) isoenzymes is significantly decreased in encapsulated cells relative to planktonic. Going forward, comparison of transcriptomic and metabolomic data obtained under identical conditions is sure to provide insight into biochemical changes that ensue following encapsulation, and further elucidate mechanism(s) by which encapsulated cells uncouple metabolism from cell division.

\section{ICRs for the identification of anti-aging compounds}

Yeast microcolonies originating from a single cell are often used in high-throughput drug screens. As the measurement of colony size can be automated, this approach allows for large numbers of anti-aging compounds to be rapidly screened [165]. An obvious disadvantage of this approach is that it relies on cell division; hence, microcolony assays may fail to identify compounds that also extend CLS
[104]. Because ICRs are populated with non-dividing, nutrient-replete cells, they offer the drug discovery process the advantage of directly assaying CLS. Though ICR-based assays are unlikely to be as easily multiplexed as those based on microcolony growth, or growth in liquid media, they could provide a valuable tool for testing whether anti-aging compounds uncovered by high-throughput assays also extend CLS.

Encapsulated, continuously-fed yeast as a model for studying chronological lifespan

In metazoans, the great majority of cells exist in a nondividing state, $G_{0}$ [166-168]. While most are terminallydifferentiated and will never divide, the lifespan of some $G_{0}$ cells approximates the lifespan of the whole organism [169, 170], during which time they operate at full metabolic capacity [171]. Encapsulated yeast confined in ICR and fed ad libitum provides a reasonable approximation to postmitotic metazoan cells like cardiac myocytes and neurons that are amply nourished but do not divide. Indeed, of all the zero-growth yeast models reviewed here, only the ICR model provides a way to study CLS in a simple eukaryote in the absence of $\mathrm{CR}$, or starvation. This model could also be adapted for the study of CLS in the presence of CR simply by limiting carbon to levels that are one-third to one-half that of cells fed ad libitum, without inducing malnutrition

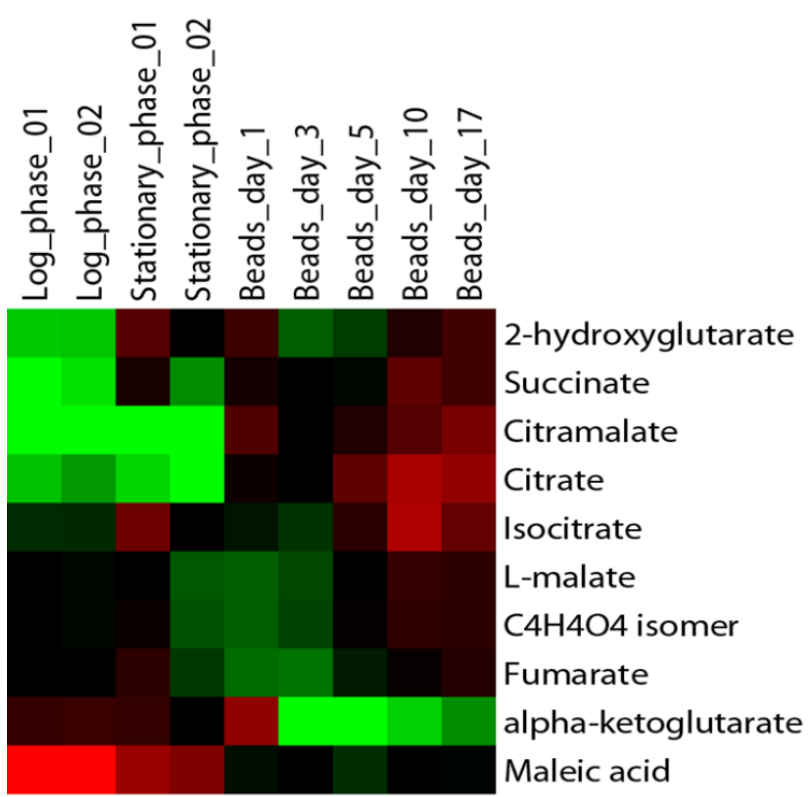

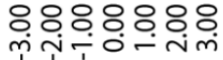

FIGURE 5: Levels of citric acid cycle metabolites in continuouslyfed encapsulated yeast differ from planktonic yeast in exponential and stationary phases. Metabolites were extracted from flashfrozen cell pellets grown in batch or in continuous culture as indicated [172] and analyzed by LC-MS using a reversed phase method. Metabolite levels were normalized to the quantity of input cells, and displayed as a log2 fold change centered around the median value for each metabolite. 
or starvation $[13,48,86,100]$. Systematic improvements that would enhance the utility of this model include: (1) multiplexing mini-ICRs so that individual columns could be sacrificially sampled over the course of weeks to months of continuous culture, (2) introducing mechanisms to sparge mini-ICRs so that CLS can be modeled under oxic and anoxic conditions, and (3) devising techniques to ensure even dispersal of diverse genotypes in a given bead, so that representatives of the barcoded yeast knock-out and overexpression collections could be studied under conditions of long-term growth arrest, either in the presence or absence of CR.

\section{CONCLUSIONS AND FUTURE DIRECTIONS}

Genetic screens using the starving yeast model have provided insight into the behavior of eukaryotic cells under prolonged stress, showing how pathways such as TOR and genes like $S I R$ are integrated and together contribute to cell survival. Because starving yeast are not dividing, this model has been used to measure CLS. As such cells are, by definition, nutrient-deprived, experimental results have been interpreted in the light of how CLS is affected by CR, a factor shown to extend longevity in virtually every species where it has been studied. But having few calories (CR) is not the same as having no calories (starvation). Thus, starving yeast does not mimic the physiology and lifespan of major classes of metazoan cells. Cardiac myocytes and neurons are terminally differentiated in a state of $\mathrm{G}_{0}$ arrest, but remain metabolically active and well-fed for the life of the organism. Muscle stem cells are also in $\mathrm{G}_{0}$-arrest and remain metabolically quiescent until recruited to enter $G_{1}$ and produce cells that differentiate into, for example, myoblasts.

Alternative culture methods exist that enable yeast researchers to circumvent this fundamental problem. Yeast in giant colonies receive low levels of nutrients by diffusion, allowing them to divide over longer periods ( $18 \mathrm{~d}$ vs. $\sim 30 \mathrm{~h}$ ) than starving planktonic cells. This longer period of slow growth contributes to the higher viability of aging cells in colonies relative to aging planktonic cells. Unlike starving planktonic cells, whose populations are not spatially structured, cells grown in colonies exhibit a primitive type of context-dependent cellular differentiation as they age, with some cell classes alive, but growing at near-zero rates. Ultimately though, yeast grown in giant colonies, like starving planktonic yeast, live in a closed, nutrientdepleted culture system that scarcely resembles a metazoan body.

Retentostats, an open system that exchanges nutrients and waste products with the environment, overcome several limitations associated with studying CLS in starving planktonic cells. Retentostat yeast is cultured at near-zero growth rates and provided with maintenance energy requirements. Retentostat yeast is under $\mathrm{CR}$, a physiological state distinct from starvation. Cell viability remains high ( $80 \%$ after 22 days) with little evidence of protein and DNA damage. Aging retentostat yeast may therefore serve as a surrogate for classes of metazoan cells that have exited the replicative cycle such as pluripotent stem cells.

A third alternative to starving planktonic yeast is encapsulated yeast, which can be cultured in ICRs at nearzero growth rates. This matrix-associated, open culture system offers flexibility in nutrient supply. Yeast can be fed ad libitum so that non-dividing cells remain viable for weeks on end, conditions that mimic metabolism and longevity in terminally-differentiated metazoan cells. ICR yeast could also be cultured under nutrient-limiting conditions, making it possible to study cells in a tissue-like matrix under CR. Nutrient levels could even be reduced to where only maintenance energy requirements are met, creating an ICR model for the study of stem cells.

Caution should be exercised in the use of starving, planktonic microbial cells to evaluate determinants of CLS in metazoan stem cells and metazoans cells that are terminally differentiated. Since these cell types have their energy requirements met, alternative systems are needed that better mimic their physiologies. Yeast growing in colonies, in retentostats, and in immobilized cell reactors all provide a higher degree of biological realism.

\section{ACKNOWLEDGMENTS}

JG was funded by NSF Graduate Research Predoctoral Fellowship DGE-1148903, NSF iCorps 1743464 and the Georgia Research Alliance (GRA.VI18.B16). EC was funded by NIAID grant 1R01-Al136992-01A1. EK and FR were funded by NASA grants NNX14AK38G-EXO and NNA17BB05A. AAC was funded by an Open Operating Grant from the Canadian Institutes for Health Research, a Discovery Grant from the Natural Sciences and Engineering Research Council of Canada and as the Canada Research Chair of Metabolomics for Enzyme Discovery.

\section{CONFLICT OF INTEREST}

The authors declare no conflict of interest.

\section{COPYRIGHT}

(C) 2019 Gulli et al. This is an open-access article released under the terms of the Creative Commons Attribution (CC BY) license, which allows the unrestricted use, distribution, and reproduction in any medium, provided the original author and source are acknowledged.

Please cite this article as: Jordan Gulli, Emily Cook, Eugene Kroll, Adam Rosebrock, Amy Caudy and Frank Rosenzweig (2019). Diverse conditions support near-zero growth in yeast: Implications for the study of cell lifespan. Microbial Cell 6(9): 397-413. doi: 10.15698/mic2019.09.690

\section{REFERENCES}

1. Flatt T (2012). A New Definition of Aging? Front Genet 3: 148. doi: 10.3389/fgene.2012.00148
2. Mortimer RK, Johnston JR (1959). Life span of individual yeast cells. Nature 183(4677): 1751-1752. doi: 10.1038/1831751a0 
3. Arlia-Ciommo A, Piano A, Leonov A, Svistkova V, Titorenko VI (2014). Quasi-programmed aging of budding yeast: a trade-off between programmed processes of cell proliferation, differentiation, stress response, survival and death defines yeast lifespan. Cell Cycle 13(21): 3336-3349. doi: 10.4161/15384101.2014.965063

4. Jo MC, Liu W, Gu L, Dang W, Qin L (2015). High-throughput analysis of yeast replicative aging using a microfluidic system. Proc Natl Acad Sci U S A 112(30): 9364-9369. doi: 10.1073/pnas.1510328112

5. Wasko BM, Kaeberlein M (2014). Yeast replicative aging: a paradigm for defining conserved longevity interventions. FEMS Yeast Res 14(1): 148-159. doi: 10.1111/1567-1364.12104

6. Stumpferl SW, Brand SE, Jiang JC, Korona B, Tiwari A, Dai J, Seo JG, Jazwinski SM (2012). Natural genetic variation in yeast longevity. Genome Res 22(10): 1963-1973. doi: 10.1101/gr.136549.111

7. Denoth Lippuner A, Julou T, Barral Y (2014). Budding yeast as a model organism to study the effects of age. FEMS Microbiol Rev 38(2): 300-325. doi: 10.1111/1574-6976.12060

8. Powers RW, 3rd, Kaeberlein M, Caldwell SD, Kennedy BK, Fields S (2006). Extension of chronological life span in yeast by decreased TOR pathway signaling. Genes Dev 20(2): 174-184. doi: 10.1101/gad.1381406

9. Burtner CR, Murakami CJ, Olsen B, Kennedy BK, Kaeberlein M (2011). A genomic analysis of chronological longevity factors in budding yeast. Cell Cycle 10(9): 1385-1396. doi: 10.4161/cc.10.9.15464

10. Garay E, Campos SE, Gonzalez de la Cruz J, Gaspar AP, Jinich A, Deluna A (2014). High-resolution profiling of stationary-phase survival reveals yeast longevity factors and their genetic interactions. PLoS Genet 10(2): e1004168. doi: 10.1371/journal.pgen.1004168

11. Burtner CR, Murakami CJ, Kennedy BK, Kaeberlein M (2009). A molecular mechanism of chronological aging in yeast. Cell Cycle 8(8): 1256-1270. doi: 10.4161/cc.8.8.8287

12. Smith DL, Jr., McClure JM, Matecic M, Smith JS (2007). Calorie restriction extends the chronological lifespan of Saccharomyces cerevisiae independently of the Sirtuins. Aging Cell 6(5): 649-662. doi: 10.1111/j.1474-9726.2007.00326.x

13. Lin S-J, Kaeberlein M, Andalis AA, Sturtz LA, Defossez P-A, Culotta VC, Fink GR, Guarente L (2002). Calorie restriction extends Saccharomyces cerevisiae lifespan by increasing respiration. Nature 418(6895):344-8. doi: 10.1038/nature00829

14. Boender LG, Almering MJ, Dijk M, van Maris AJ, de Winde JH, Pronk JT, Daran-Lapujade $P$ (2011). Extreme calorie restriction and energy source starvation in Saccharomyces cerevisiae represent distinct physiological states. Biochim Biophys acta 1813(12): 2133-2144. doi: 10.1016/j.bbamcr.2011.07.008

15. Zorova LD, Popkov VA, Plotnikov EY, Silachev DN, Pevzner IB, Jankauskas SS, Babenko VA, Zorov SD, Balakireva AV, Juhaszova M, Sollott SJ, Zorov DB (2018). Mitochondrial membrane potential. Anal Biochem 552: 50-59. doi: 10.1016/j.ab.2017.07.009

16. Delaney JR, Murakami C, Chou A, Carr D, Schleit J, Sutphin GL, An EH, Castanza AS, Fletcher M, Goswami S, Higgins S, Holmberg M, Hui J, Jelic $M$, Jeong KS, Kim JR, Klum S, Liao E, Lin MS, Lo W, Miller H, Moller R, Peng ZJ, Pollard T, Pradeep P, Pruett D, Rai D, Ros V, Schuster A, Singh $M$, et al. (2013). Dietary restriction and mitochondrial function link replicative and chronological aging in Saccharomyces cerevisiae. Exp Gerontol 48(10): 1006-1013. doi: 10.1016/j.exger.2012.12.001

17. Miceli MV, Jiang JC, Tiwari A, Rodriguez-Quinones JF, Jazwinski SM (2011). Loss of mitochondrial membrane potential triggers the retrograde response extending yeast replicative lifespan. Front Genet 2: 102. doi: 10.3389/fgene.2011.00102
18. Qin H, Lu M (2006). Natural variation in replicative and chronological life spans of Saccharomyces cerevisiae. Exp Gerontol 41(4): 448456. doi: 10.1016/j.exger.2006.01.007

19. Kwan EX, Foss E, Kruglyak L, Bedalov A (2011). Natural polymorphism in BUL2 links cellular amino acid availability with chronological aging and telomere maintenance in yeast. PLoS Genet 7(8): e1002250. doi: 10.1371/journal.pgen.1002250

20. Burtner CR, Murakami CJ, Olsen B, Kennedy BK, Kaeberlein M (2011). A genomic analysis of chronological longevity factors in budding yeast. Cell Cycle 10(9): 1385-1396. doi: 10.4161/cc.10.9.15464

21. Garay E, Campos SE, González de la Cruz J, Gaspar AP, Jinich A, DeLuna A (2014). High-Resolution Profiling of Stationary-Phase Survival Reveals Yeast Longevity Factors and Their Genetic Interactions. PLOS Genet 10(2): e1004168. doi: 10.1371/journal.pgen.1004168

22. Delaney JR, Murakami C, Chou A, Carr D, Schleit J, Sutphin GL, An EH, Castanza AS, Fletcher M, Goswami S, Higgins S, Holmberg M, Hui J, Jelic $M$, Jeong K-S, Kim JR, Klum S, Liao E, Lin MS, Lo W, Miller $H$, Moller R, Peng ZJ, Pollard T, Pradeep P, Pruett D, Rai D, Ros V, Schuster $A$, Singh $M$, et al. (2013). Dietary restriction and mitochondrial function link replicative and chronological aging in Saccharomyces cerevisiae. Exp Gerontol 48(10): 1006-1013. doi: 10.1016/j.exger.2012.12.001

23. Wei M, Madia F, Longo VD (2011). Studying age-dependent genomic instability using the $S$. cerevisiae chronological lifespan model. J Vis Exp 55: 3030. doi: 10.3791/3030

24. Fontana L, Partridge L, Longo VD (2010). Extending healthy life span--from yeast to humans. Science 328(5976): 321-326. doi: 10.1126/science.1172539

25. Swinnen E, Ghillebert R, Wilms T, Winderickx J (2014). Molecular mechanisms linking the evolutionary conserved TORC1-Sch9 nutrient signalling branch to lifespan regulation in Saccharomyces cerevisiae. FEMS Yeast Res 14(1): 17-32. doi: 10.1111/1567-1364.12097

26. Longo VD, Fabrizio P (2012). Chronological Aging in Saccharomyces cerevisiae. Subcell Biochem 57: 101-121. doi: 10.1007/978-94-0072561-4_5

27. He C, Zhou C, Kennedy BK (2018). The yeast replicative aging model. Biochim Biophys Acta 1864(9, Part A): 2690-2696. doi: 10.1016/j.bbadis.2018.02.023

28. Bourre JM (2006). Effects of nutrients (in food) on the structure and function of the nervous system: update on dietary requirements for brain. Part 2 : macronutrients. J Nutr Health Aging 10(5): 386-399. PMID: 17066210

29. Bergmann O, Zdunek S, Felker A, Salehpour M, Alkass K, Bernard S, Sjostrom S, Szewczykowska M, Jackowska T, dos Remedios C, Malm T, Andrä M, Jashari R, R Nyengaard J, Possnert G, Jovinge $S$, Druid $H$, Frisén J (2015). Dynamics of Cell Generation and Turnover in the Human Heart. Cell 161(7):1566-75. doi: 10.1016/j.cell.2015.05.026

30. Montarras D, L'Honore A, Buckingham M (2013). Lying low but ready for action: the quiescent muscle satellite cell. Febs J 280(17): 4036-4050. doi: 10.1111/febs.12372

31. Takubo K, Nagamatsu G, Kobayashi Chiharu I, Nakamura-Ishizu A, Kobayashi H, Ikeda E, Goda N, Rahimi Y, Johnson Randall S, Soga T, Hirao A, Suematsu M, Suda T (2013). Regulation of Glycolysis by Pdk Functions as a Metabolic Checkpoint for Cell Cycle Quiescence in Hematopoietic Stem Cells. Cell Stem Cell 12(1): 49-61. doi: 10.1016/j.stem.2012.10.011

32. Kocabas F, Xie L, Xie J, Yu Z, DeBerardinis RJ, Kimura W, Thet $\mathrm{S}$, Elshamy AF, Abouellail H, Muralidhar S, Liu X, Chen C, Sadek HA, Zhang CC, Zheng J (2015). Hypoxic metabolism in human hematopoietic stem cells. Cell Biosci 5: 39. doi: 10.1186/s13578-015-0020-3. 
33. Hu J, Wei M, Mirisola MG, Longo VD (2013). Assessing chronological Aging in Saccharomyces cerevisiae. Methods Mol Biol 965: 463472. doi: 10.1007/978-1-62703-239-1_30

34. Mináriková L, Kuthan M, Řičicová M, Forstová J, Palková Z (2001). Differentiated Gene Expression in Cells within Yeast Colonies. Exp Cell Res 271(2): 296-304. doi: 10.1006/excr.2001.5379

35. Palkova Z, Vachova L, Gaskova D, Kucerova H (2009). Synchronous plasma membrane electrochemical potential oscillations during yeast colony development and aging. Mol Membr Biol 26(4): 228-235. doi: 10.1080/09687680902893130

36. Váchová L, Čáp M, Palková Z (2012). Yeast Colonies: A Model for Studies of Aging, Environmental Adaptation, and Longevity. Oxid Med Cell Longev 2012: 601836. doi: 10.1155/2012/601836

37. Vachova L, Hatakova L, Cap M, Pokorna M, Palkova Z (2013). Rapidly developing yeast microcolonies differentiate in a similar way to aging giant colonies. Oxid Med Cell Longev 2013: 102485. doi: $10.1155 / 2013 / 102485$

38. Cap M, Stepanek L, Harant K, Vachova L, Palkova Z (2012). Cell differentiation within a yeast colony: metabolic and regulatory parallels with a tumor-affected organism. Mol Cell 46(4): 436-448. doi: 10.1016/j.molcel.2012.04.001

39. Alberts $B$, Johnson $A$, Lewis J, Raff $M$, Roberts $K$ and Walter $P$ (2002). Molecular Biology of the Cell. Garland Sciences, New York.

40. Vachova L, Palkova Z (2011). Aging and longevity of yeast colony populations: metabolic adaptation and differentiation. Biochem Soc Trans 39(5): 1471-1475. doi: 10.1042/bst0391471

41. Marinkovic ZS, Vulin C, Acman $M$, Song $X$, Di Meglio JM, Lindner $A B$, Hersen $P$ (2019). A microfluidic device for inferring metabolic landscapes in yeast monolayer colonies. Elife 8: e47951. doi: 10.7554/eLife.47951

42. Meunier JR, Choder M (1999). Saccharomyces cerevisiae colony growth and ageing: biphasic growth accompanied by changes in gene expression. Yeast 15(12): 1159-1169. doi: 10.1002/(sici)10970061(19990915)15:12<1159::aid-yea441>3.0.co;2-d

43. Oliver JD (2005). The viable but nonculturable state in bacteria. J Microbiol 43(1): 93-100. PMID: 15765062

44. Fabrizio P, Battistella L, Vardavas R, Gattazzo C, Liou LL, Diaspro A, Dossen JW, Gralla EB, Longo VD (2004). Superoxide is a mediator of an altruistic aging program in Saccharomyces cerevisiae. J Cell Biol 166(7): 1055-1067. doi: 10.1083/jcb.200404002

45. Fabrizio P, Battistella L, Vardavas R, Gattazzo C, Liou L-L, Diaspro A, Dossen JW, Gralla EB, Longo VD (2004). Superoxide is a mediator of an altruistic aging program in Saccharomyces cerevisiae. J Cell Biol 166(7): 1055-1067. doi: 10.1083/jcb.200404002

46. Vachova L, Palkova Z (2005). Physiological regulation of yeast cell death in multicellular colonies is triggered by ammonia. J Cell Biol 169(5): 711-717. doi: 10.1083/jcb.200410064

47. Piper PW, Harris NL, MacLean M (2006). Preadaptation to efficient respiratory maintenance is essential both for maximal longevity and the retention of replicative potential in chronologically ageing yeast. Mech Ageing Dev 127(9): 733-740. doi: 10.1016/j.mad.2006.05.004

48. Kaeberlein M, Hu D, Kerr EO, Tsuchiya M, Westman EA, Dang N, Fields S, Kennedy BK (2005). Increased life span due to calorie restriction in respiratory-deficient yeast. PLoS Genet 1(5): e69. doi: 10.1371/journal.pgen.0010069

49. Lee C, Longo V (2016). Dietary restriction with and without caloric restriction for healthy aging. F1000Research 5. doi: 10.12688/f1000research.7136.1
50. Vachova L, Cap M, Palkova Z (2012). Yeast colonies: a model for studies of aging, environmental adaptation, and longevity. Oxid Med Cell Longev 2012: 601836. doi: 10.1155/2012/601836

51. Váchová L, Palková Z (2018). How structured yeast multicellular communities live, age and die? FEMS Yeast Res 18(4). doi: 10.1093/femsyr/foy033

52. Palkova Z, Devaux F, Icicova M, Minarikova L, Le Crom S, Jacq C (2002). Ammonia pulses and metabolic oscillations guide yeast colony development. Mol Biol Cell 13(11): 3901-3914. doi: 10.1091/mbc.e0112-0149

53. Palkova Z, Vachova L (2006). Life within a community: benefit to yeast long-term survival. FEMS Microbiol Rev 30(5): 806-824. doi: 10.1111/j.1574-6976.2006.00034.x

54. Vachova L, Kucerova H, Devaux F, Ulehlova M, Palkova Z (2009). Metabolic diversification of cells during the development of yeast colonies. Environ Microbiol 11(2): 494-504. doi: 10.1111/j.14622920.2008.01789.x

55. Palková Z, Váchová L (2003). Ammonia signaling in yeast colony formation. Int Rev Cytol 225: 229-272. doi: 10.1016/s00747696(05)25006-4

56. Čáp M, Štěpánek L, Harant K, Váchová L, Palková Z (2012). Cell Differentiation within a Yeast Colony: Metabolic and Regulatory Parallels with a Tumor-Affected Organism. Mol Cell 46(4): 436-448. doi: 10.1016/j.molcel.2012.04.001

57. Wilkinson D, Marsikova J, Hlavacek O, Gilfillan GD, Jezkova E, Aalokken R, Vachova L, Palkova Z (2018). Transcriptome Remodeling of Differentiated Cells during Chronological Ageing of Yeast Colonies: New Insights into Metabolic Differentiation. Oxid Med Cell Longev 2018: 4932905. doi: 10.1155/2018/4932905

58. Hinnebusch AG (2005). Translational regulation of GCN4 and the general amino acid control of yeast. Annu Rev Microbiol 59: 407-450. doi: 10.1146/annurev.micro.59.031805.133833

59. Palkova Z, Wilkinson D, Vachova L (2014). Aging and differentiation in yeast populations: elders with different properties and functions. FEMS Yeast Res 14(1): 96-108. doi: 10.1111/1567-1364.12103

60. Cap M, Vachova L, Palkova Z (2009). Yeast colony survival depends on metabolic adaptation and cell differentiation rather than on stress defense. J Biol Chem 284(47):32572-81. doi: 10.1074/jbc.M109.022871

61. Čáp M, Váchová L, Palková Z (2010). How to survive within a yeast colony. Commun Integr Biol 3(2): 198-200. doi: 10.4161/cib.3.2.11026

62. Kourtis N, Tavernarakis N (2011). Cellular stress response pathways and ageing: intricate molecular relationships. EMBO J 30(13): 2520-2531. doi: 10.1038/emboj.2011.162

63. Gralla EB, Valentine JS (1991). Null mutants of Saccharomyces cerevisiae $\mathrm{Cu}, \mathrm{Zn}$ superoxide dismutase: characterization and spontaneous mutation rates. J Bacteriol 173(18): 5918-5920. doi: 10.1128/jb.173.18.5918-5920.1991

64. Longo VD, Gralla EB, Valentine JS (1996). Superoxide dismutase activity is essential for stationary phase survival in Saccharomyces cerevisiae. Mitochondrial production of toxic oxygen species in vivo. J Biol Chem 271(21): 12275-12280. doi: 10.1074/jbc.271.21.12275

65. Leontieva OV, Blagosklonny MV (2011). Yeast-like chronological senescence in mammalian cells: phenomenon, mechanism and pharmacological suppression. Aging 3(11): 1078-1091. doi: 10.18632/aging.100402

66. Arismendi-Morillo GJ, Castellano-Ramirez AV (2008). Ultrastructural mitochondrial pathology in human astrocytic tumors: potentials implications pro-therapeutics strategies. J Electron Microsc 57(1): 3339. doi: 10.1093/jmicro/dfm038 
67. Eng CH, Yu K, Lucas J, White E, Abraham RT (2010). Ammonia derived from glutaminolysis is a diffusible regulator of autophagy. Sci Signal 3(119): ra31-ra31. doi: 10.1126/scisignal.2000911

68. Čáp M, Váchová L, Palková Z (2015). Longevity of U cells of differentiated yeast colonies grown on respiratory medium depends on active glycolysis. Cell Cycle 14(21): 3488-3497. doi: 10.1080/15384101.2015.1093706

69. DeBerardinis RJ, Cheng T (2010). Q's next: the diverse functions of glutamine in metabolism, cell biology and cancer. Oncogene 29(3): 313-324. doi: 10.1038/onc.2009.358

70. Burnetti AJ, Aydin M, Buchler NE, Solomon MJ (2015). Cell cycle Start is coupled to entry into the yeast metabolic cycle across diverse strains and growth rates. Mol Biol Cell 27(1): 64-74. doi: 10.1091/mbc.e15-07-0454

71. Westman JO, Bonander N, Taherzadeh MJ, Franzen CJ (2014). Improved sugar co-utilisation by encapsulation of a recombinant Saccharomyces cerevisiae strain in alginate-chitosan capsules. Biotechnol Biofuels 7: 102. doi: 10.1186/1754-6834-7-102

72. Herbert D (1961). A theoretical analysis of continuous culture systems. In: Hastings DW, editor. Continuous culture of microorganisms. Society of Chemical Industry, London, United Kingdon; pp 2153.

73. Monod J (1950). La technique de culture continue: theorie et applications. Ann Inst Pasteur 79: 390-410.

74. Novick A, Szilard L (1950). Description of the chemostat. Science 112(2920): 715-716. doi_10.1126/science.112.2920.715

75. Edmunds LN (1972). Introduction to Research with Continuous Cultures. H. E. Kubitschek. Q Rev Biol 47(1): 88-88. doi: $10.1086 / 407133$

76. Kubitschek HE (1954). Modifications of the chemostat. J Bacteriol 67(2): 254-255. PMID: 13129224

77. Novick A, Szilard L (1950). Experiments with the Chemostat on spontaneous mutations of bacteria. Proc Natl Acad Sci U S A 36(12): 708-719. doi: 10.1073/pnas.36.12.708

78. Boender LG, de Hulster EA, van Maris AJ, Daran-Lapujade PA Pronk JT (2009). Quantitative physiology of Saccharomyces cerevisiae at near-zero specific growth rates. Appl Environ Microbiol 75(17) 5607-5614. doi: 10.1128/aem.00429-09

79. Boender LG, van Maris AJ, de Hulster EA, Almering MJ, van der Kle IJ, Veenhuis M, de Winde JH, Pronk JT, Daran-Lapujade P (2011). Cellular responses of Saccharomyces cerevisiae at near-zero growth rates: transcriptome analysis of anaerobic retentostat cultures. FEMS Yeast Res 11(8): 603-620. doi: 10.1111/j.1567-1364.2011.00750.x

80. Lewis JG, Northcott CJ, Learmonth RP, Attfield PV, Watson K (1993). The need for consistent nomenclature and assessment of growth phases in diauxic cultures of Saccharomyces cerevisiae. Microbiol 139(4): 835-839. doi: doi:10.1099/00221287-139-4-835

81. Foss EJ, Lao U, Dalrymple E, Adrianse RL, Loe T, Bedalov A (2017) $<$ em $>$ SIR2 $</$ em $>$ suppresses replication gaps and genome instability by balancing replication between repetitive and unique sequences. Proc Natl Acad Sci U S A 114(3): 552-557. doi 10.1073/pnas.1614781114

82. Bellizzi D, Rose G, Cavalcante $P$, Covello $G$, Dato $S$, De Rango $F$ Greco V, Maggiolini M, Feraco E, Mari V, Franceschi C, Passarino G, De Benedictis $G$ (2005). A novel VNTR enhancer within the SIRT3 gene, a human homologue of SIR2, is associated with survival at oldest ages. Genomics 85(2): 258-263. doi: 10.1016/j.ygeno.2004.11.003

83. Smith JT, White JW, Dungrawala H, Hua H, Schneider BL (2018). Yeast lifespan variation correlates with cell growth and SIR2 expression. PLOS ONE 13(7): e0200275. doi: 10.1371/journal.pone.0200275
84. Bellizzi D, Rose G, Cavalcante P, Covello G, Dato S, De Rango F, Greco V, Maggiolini M, Feraco E, Mari V, Franceschi C, Passarino G, De Benedictis $G$ (2005). A novel VNTR enhancer within the SIRT3 gene, a human homologue of SIR2, is associated with survival at oldest ages. Genomics 85(2): 258-263. doi: 10.1016/j.ygeno.2004.11.003

85. Boender LGM, Almering MJH, Dijk M, van Maris AJA, de Winde JH, Pronk JT, Daran-Lapujade $P$ (2011). Extreme calorie restriction and energy source starvation in Saccharomyces cerevisiae represent dis tinct physiological states. Biochim Biophys Acta 1813(12): 2133-2144. doi: 10.1016/j.bbamcr.2011.07.008

86. Binai NA, Bisschops MM, van Breukelen B, Mohammed S, Loeff L, Pronk JT, Heck AJ, Daran-Lapujade P, Slijper M (2014). Proteome adaptation of Saccharomyces cerevisiae to severe calorie restriction in Retentostat cultures. J Proteome Res 13(8): 3542-3553. doi: 10.1021/pr5003388

87. Webb KJ, Xu T, Park SK, Yates JR, 3rd (2013). Modified MuDPIT separation identified 4488 proteins in a system-wide analysis of quiescence in yeast. J Proteome Res 12(5): 2177-2184. doi: $10.1021 / \mathrm{pr} 400027 \mathrm{~m}$

88. Binai NA, Bisschops MMM, van Breukelen B, Mohammed S, Loeff L, Pronk JT, Heck AJR, Daran-Lapujade P, Slijper M (2014). Proteome Adaptation of Saccharomyces cerevisiae to Severe Calorie Restriction in Retentostat Cultures. J Proteome Res 13(8): 3542-3553. doi: 10.1021/pr5003388

89. Camarasa C, Grivet J-P, Dequin S (2003). Investigation by $13 C-N M R$ and tricarboxylic acid (TCA) deletion mutant analysis of pathways for succinate formation in Saccharomyces cerevisiae during anaerobic fermentation. Microbiol 149(9): 2669-2678. doi: doi:10.1099/mic.0.26007-0

90. He W, Parker R (2000). Functions of Lsm proteins in mRNA degradation and splicing. Curr Opin Cell Biol 12(3): 346-350. doi: 10.1016/s0955-0674(00)00098-3

91. Fuge EK, Braun EL, Werner-Washburne M (1994). Protein synthesis in long-term stationary-phase cultures of Saccharomyces cerevisiae. J Bacteriol 176(18): 5802-5813. doi: 10.1128/jb.176.18.5802-5813.1994

92. Marguerat S, Schmidt A, Codlin S, Chen W, Aebersold R, Bahler J (2012). Quantitative analysis of fission yeast transcriptomes and proteomes in proliferating and quiescent cells. Cell 151(3): 671-683. doi: 10.1016/j.cell.2012.09.019

93. Helbig AO, Daran-Lapujade $P$, van Maris AJ, de Hulster EA, de Ridder D, Pronk JT, Heck AJ, Slijper M (2011). The diversity of protein turnover and abundance under nitrogen-limited steady-state conditions in Saccharomyces cerevisiae. Mol Biosys 7(12): 3316-3326. doi: 10.1039/c1mb05250k

94. Wang Y, Liu CL, Storey JD, Tibshirani RJ, Herschlag D, Brown PO (2002). Precision and functional specificity in mRNA decay. Proc Natl Acad Sci U S A 99(9): 5860-5865. doi: 10.1073/pnas.092538799

95. Verduyn C, Postma E, Scheffers WA, van Dijken JP (1990). Energetics of Saccharomyces cerevisiae in anaerobic glucose-limited chemostat cultures. J Gen Microbiol 136(3): 405-412. doi 10.1099/00221287-136-3-405

96. Beck T, Schmidt A, Hall MN (1999). Starvation Induces Vacuolar Targeting and Degradation of the Tryptophan Permease in Yeast. J Cell Biol 146(6): 1227-1238. doi: 10.1083/jcb.146.6.1227

97. Albers E, Larsson C, Andlid T, Walsh MC, Gustafsson L (2007). Effect of Nutrient Starvation on the Cellular Composition and Metabolic Capacity of Saccharomyces cerevisiae. Appl Environ Microbiol 73(15): 4839-4848. doi: 10.1128/aem.00425-07

98. Jones CB, Ott EM, Keener JM, Curtiss M, Sandrin V, Babst M (2012). Regulation of membrane protein degradation by starvation- 
response pathways. Traffic 13(3): 468-482. doi: 10.1111/j.16000854.2011.01314.x

99. Suzuki SW, Onodera J, Ohsumi Y (2011). Starvation induced cell death in autophagy-defective yeast mutants is caused by mitochondria dysfunction. PLoS One 6(2): e17412. doi: 10.1371/journal.pone.0017412

100. Wei M, Fabrizio P, Hu J, Ge H, Cheng C, Li L, Longo VD (2008). Life span extension by calorie restriction depends on Rim15 and transcription factors downstream of Ras/PKA, Tor, and Sch9. PLoS Genet 4(1): e13. doi: 10.1371/journal.pgen.0040013

101. Stouthamer AH (1973). A theoretical study on the amount of ATP required for synthesis of microbial cell material. Antonie Van Leeuwenhoek 39(1): 545-565. doi: 10.1007/bf02578899

102. Allen C, Büttner S, Aragon AD, Thomas JA, Meirelles O, Jaetao JE, Benn D, Ruby SW, Veenhuis M, Madeo F, Werner-Washburne M (2006). Isolation of quiescent and nonquiescent cells from yeast stationary-phase cultures. J Cell Biol 174(1): 89-100. doi: 10.1083/jcb.200604072

103. Bisschops MMM, Luttik MAH, Doerr A, Verheijen PJT, Bruggeman F, Pronk JT, Daran-Lapujade P (2017). Extreme calorie restriction in yeast retentostats induces uniform non-quiescent growth arrest. Biochim Biophys Acta 1864(1): 231-242. doi: 10.1016/j.bbamcr.2016.11.002

104. Zimmermann A, Kainz K, Hofer S, Pendl T, Carmona-Gutierrez D, Madeo $F(2018)$. Yeast as a tool to identify anti-aging compounds. FEMS Yeast Res 18(6). doi: 10.1093/femsyr/foy020

105. Gonzalez LM, Stewart AS, Freund J, Kucera CR, Dekaney CM, Magness ST, Blikslager AT (2019). Preservation of reserve intestinal epithelial stem cells following severe ischemic injury. Am J Physiol Gastrointest Liver Physiol 316(4): G482-G494. doi: 10.1152/ajpgi.00262.2018

106. Sato M, Kawana K, Adachi K, Fujimoto A, Yoshida M, Nakamura $\mathrm{H}$, Nishida H, Inoue T, Taguchi A, Ogishima J, Eguchi S, Yamashita A, Tomio K, Wada-Hiraike O, Oda K, Nagamatsu T, Osuga Y, Fujii T (2017). Regeneration of cervical reserve cell-like cells from human induced pluripotent stem cells (iPSCs): A new approach to finding targets for cervical cancer stem cell treatment. Oncotarget 8(25): 40935-40945. doi: 10.18632/oncotarget.16783

107. Bisschops MMM, Zwartjens P, Keuter SGF, Pronk JT, DaranLapujade $P$ (2014). To divide or not to divide: A key role of Rim15 in calorie-restricted yeast cultures. Biochim Biophys Acta 1843(5): 10201030. doi: 10.1016/j.bbamcr.2014.01.026

108. Hanahan D, Weinberg RA (2000). The hallmarks of cancer. Cell 100(1): 57-70. doi: 10.1016/s0092-8674(00)81683-9

109. Vos T, Hakkaart XD, de Hulster EA, van Maris AJ, Pronk JT, DaranLapujade $P$ (2016). Maintenance-energy requirements and robustness of Saccharomyces cerevisiae at aerobic near-zero specific growth rates. Microb Cell Fact 15(1): 111. doi: 10.1186/s12934-016-0501-z

110. Sauer M, Mattanovich D (2016). Non-genetic impact factors on chronological lifespan and stress resistance of baker's yeast. Microbial Cell 3(6): 232-235. doi: 10.15698/mic2016.06.504

111. Ercan O, Bisschops MM, Overkamp W, Jorgensen TR, Ram AF, Smid EJ, Pronk JT, Kuipers OP, Daran-Lapujade P, Kleerebezem M (2015). Physiological and Transcriptional Responses of Different Industrial Microbes at Near-Zero Specific Growth Rates. App Environ Microbiol 81(17): 5662-5670. doi: 10.1128/aem.00944-15

112. Drury JL, Mooney DJ (2003). Hydrogels for tissue engineering: scaffold design variables and applications. Biomaterials 24(24): 4337 4351. doi: 10.1016/s0142-9612(03)00340-5
113. Nussinovitch A (2010). Polymer Macro- and Micro-Gel Beads: Fundamentals and Applications. Springer, New York. doi: 10.1007/978-1-4419-6618-6

114. Nedović V, Gibson B, Mantzouridou TF, Bugarski B, Djordjević V, Kalušević $A$, Paraskevopoulou A, Sandell $M$, Šmogrovičová $D$, Yilmaztekin $M$ (2015). Aroma formation by immobilized yeast cells in fermentation processes. Yeast 32(1): 173-216. doi: 10.1002/yea.3042

115. Verrills NM (2006). Clinical proteomics: present and future prospects. Clinical Biochem Rev 27(2): 99-116. PMID: 17077880

116. Norton S, D'Amore T (1994). Physiological effects of yeast cell immobilization: Applications for brewing. Enzyme and Microbial Technology 16(5): 365-375. doi: 10.1016/0141-0229(94)90150-3

117. Talebnia F, Taherzadeh MJ (2007). Physiological and morphological study of encapsulated Saccharomyces cerevisiae. Enzyme and Microbial Technology 41(6): 683-688. doi: 10.1016/j.enzmictec.2007.05.020

118. Plessas S, Bekatorou A, Koutinas AA, Soupioni M, Banat IM, Marchant R (2007). Use of Saccharomyces cerevisiae cells immobilized on orange peel as biocatalyst for alcoholic fermentation. Bioresour Technol 98(4): 860-865. doi: 10.1016/j.biortech.2006.03.014

119. Li G-Y, Huang K-L, Jiang Y-R, Ding $P$ (2007). Production of (R)mandelic acid by immobilized cells of Saccharomyces cerevisiae on chitosan carrier. Process Biochemistry 42(10): 1465-1469. doi: 10.1016/j.procbio.2007.06.015

120. Behera S, Mohanty RC, Ray RC (2011). Ethanol production from mahula (Madhuca latifolia L.) flowers with immobilized cells of Saccharomyces cerevisiae in Luffa cylindrica L. sponge discs. Applied Energy 88(1): 212-215. doi: 10.1016/j.apenergy.2010.07.035

121. Verbelen PJ, De Schutter DP, Delvaux F, Verstrepen KJ, Delvaux FR (2006). Immobilized yeast cell systems for continuous fermentation applications. Biotechnol Lett 28(19): 1515-1525. doi: 10.1007/s10529006-9132-5

122. Krisch J, Szajani B (1997). Ethanol and acetic acid tolerance in free and immobilized cells of Saccharomyces cerevisiae and Acetobacter aceti. Biotechnol Lett 19(6): 525-528. doi: 10.1023/a:1018329118396

123. Taipa MA, Cabral JM, Santos H (1993). Comparison of glucose fermentation by suspended and gel-entrapped yeast cells: An in vivo nuclear magnetic resonance study. Biotechnol Bioeng 41(6): 647-653. doi: 10.1002/bit.260410607

124. Qun J, Shanjing Y, Lehe M (2002). Tolerance of immobilized baker's yeast in organic solvents. Enzyme and Microbial Technology 30(6): 721-725. doi: 10.1016/S0141-0229(02)00048-0

125. Desimone MF, Degrossi J, D'Aquino M, Diaz LE (2003). Sol-gel immobilisation of Saccharomyces cerevisiae enhances viability in organic media. Biotechnol Lett 25(9): 671-674. doi: 10.1023/a:1023481304479

126. Zaldivar J, Nielsen J, Olsson L (2001). Fuel ethanol production from lignocellulose: a challenge for metabolic engineering and process integration. Appl Microbiol Biotechnol 56(1-2): 17-34. doi: 10.1007/s002530100624

127. Sun Z-J, Lv G-J, Li S-Y, Xie Y-B, Yu W-T, Wang W, Ma X-J (2007). Probing the role of microenvironment for microencapsulated Sacchromyces cerevisiae under osmotic stress. J Biotechnol 128(1): 150161. doi: 10.1016/j.jbiotec.2006.09.001

128. Ylitervo P, Franzen CJ, Taherzadeh MJ (2011). Ethanol production at elevated temperatures using encapsulation of yeast. J Biotechnol 156(1): 22-29. doi: 10.1016/j.jbiotec.2011.07.018

129. Galazzo JL, Bailey JE (1990). Growing Saccharomyces cerevisiae in calcium-alginate beads induces cell alterations which accelerate glu- 
cose conversion to ethanol. Biotechnol Bioeng 36(4): 417-426. doi: doi:10.1002/bit.260360413

130. Nussinovitch A (2010). Bead Formation, Strengthening, and Modification. In: Nussinovitch A, editor Polymer Macro- and Micro-Gel Beads: Fundamentals and Applications. Springer, New York; pp 27-52.

131. Doran PM, Bailey JE (1986). Effects of immobilization on growth, fermentation properties, and macromolecular composition of Saccharomyces cerevisiae attached to gelatin. Biotechnol Bioeng 28(1): 7387. doi: doi:10.1002/bit.260280111

132. Nagarajan $S$, Kruckeberg $A L$, Schmidt $K H$, Kroll E, Hamilton $M$, McInnerney K, Summers R, Taylor T, Rosenzweig F (2014). Uncoupling reproduction from metabolism extends chronological lifespan in yeast. Proc Natl Acad Sci U S A 111(15): E1538-1547. doi: 10.1073/pnas.1323918111

133. Goossens KV, lelasi FS, Nookaew I, Stals I, Alonso-Sarduy L, Daenen L, Van Mulders SE, Stassen C, van Eijsden RG, Siewers V, Delvaux FR, Kasas S, Nielsen J, Devreese B, Willaert RG (2015). Molecular mechanism of flocculation self-recognition in yeast and its role in mating and survival. mBio 6(2). doi: 10.1128/mBio.00427-15

134. Alexandre H (2013). Flor yeasts of Saccharomyces cerevisiae-their ecology, genetics and metabolism. Int J Food Microbiol 167(2): 269-275. doi: 10.1016/j.ijfoodmicro.2013.08.021

135. Honigberg SM (2011). Cell Signals, Cell Contacts, and the Organization of Yeast Communities. Eukar Cell 10(4): 466-473. doi: 10.1128/EC.00313-10

136. Goossens K, Willaert R (2010). Flocculation protein structure and cell-cell adhesion mechanism in Saccharomyces cerevisiae. Biotechnol Lett 32(11): 1571-1585. doi: 10.1007/s10529-010-0352-3

137. Bruckner S, Mosch HU (2012). Choosing the right lifestyle: adhesion and development in Saccharomyces cerevisiae. FEMS Microbiol Rev 36(1): 25-58. doi: 10.1111/j.1574-6976.2011.00275.x

138. Koschwanez JH, Foster KR, Murray AW (2013). Improved use of a public good selects for the evolution of undifferentiated multicellularity. eLife 2: e00367. doi: 10.7554/eLife.00367

139. Ratcliff WC, Denison RF, Borrello M, Travisano M (2012). Experimental evolution of multicellularity. Proc Natl Acad Sci U S A 109(5): 1595-1600. doi: 10.1073/pnas.1115323109

140. Holmes DL, Lancaster AK, Lindquist S, Halfmann R (2013). Heritable remodeling of yeast multicellularity by an environmentally responsive prion. Cell 153(1): 153-165. doi: 10.1016/j.cell.2013.02.026

141. Oud B, Guadalupe-Medina V, Nijkamp JF, de Ridder D, Pronk JT, van Maris AJ, Daran JM (2013). Genome duplication and mutations in ACE2 cause multicellular, fast-sedimenting phenotypes in evolved Saccharomyces cerevisiae. Proc Natl Acad Sci U S A 110(45): E42234231. doi: 10.1073/pnas.1305949110

142. Lei J, Zhao X, Ge X, Bai F (2007). Ethanol tolerance and the variation of plasma membrane composition of yeast floc populations with different size distribution. J Biotechnol 131(3): 270-275. doi: 10.1016/j.jbiotec.2007.07.937

143. Jeffries TW, Jin YS (2000). Ethanol and thermotolerance in the bioconversion of xylose by yeasts. Adv Appl Microbiol 47: 221-268. doi: 10.1016/s0065-2164(00)47006-1

144. Claro FB, Rijsbrack K, Soares EV (2007). Flocculation onset in Saccharomyces cerevisiae: effect of ethanol, heat and osmotic stress. J App Microbiol 102(3): 693-700. doi: 10.1111/j.13652672.2006.03130.x

145. Westman JO, Mapelli V, Taherzadeh MJ, Franzén CJ (2014). Flocculation Causes Inhibitor Tolerance in Saccharomyces cerevisiae for Second-Generation Bioethanol Production. App Environ Microbiol 80(22): 6908-6918. doi: 10.1128/AEM.01906-14
146. Westman JO, Taherzadeh MJ, Franzen CJ (2012). Proteomic analysis of the increased stress tolerance of saccharomyces cerevisiae encapsulated in liquid core alginate-chitosan capsules. PLoS One 7(11): e49335. doi: 10.1371/journal.pone.0049335

147. Wang Y, Dohlman HG (2004). Pheromone signaling mechanisms in yeast: a prototypical sex machine. Science 306(5701): 1508-1509. doi: 10.1126/science.1104568

148. Avbelj M, Zupan J, Raspor P (2016). Quorum-sensing in yeast and its potential in wine making. Appl Microbiol Biotechnol 100(18): 7841-7852. doi: 10.1007/s00253-016-7758-3

149. Albuquerque $P$, Casadevall A (2012). Quorum sensing in fungi--a review. Med Mycol 50(4): 337-345. doi 10.3109/13693786.2011.652201

150. Richard $P$ (2003). The rhythm of yeast. FEMS Microbiol Rev 27(4): 547-557. doi: 10.1016/s0168-6445(03)00065-2

151. Amemiya T, Obase K, Hiramatsu N, Itoh K, Shibata K, Takinoue M, Yamamoto T, Yamaguchi T (2015). Collective and individual glycolytic oscillations in yeast cells encapsulated in alginate microparticles. Chaos 25(6): 064606. doi: 10.1063/1.4921692

152. Shibata K, Amemiya T, Kawakita Y, Obase K, Itoh K, Takinoue M, Nakata S, Yamaguchi T (2018). Promotion and inhibition of synchronous glycolytic oscillations in yeast by chitosan. Febs J 285(14): 2679 2690. doi: 10.1111/febs.14513

153. Lin C-C, Anseth KS (2011). Cell-cell communication mimicry with poly(ethylene glycol) hydrogels for enhancing $\beta$-cell function. Proc Natl Acad Sci U S A 108(16): 6380-6385. doi: 10.1073/pnas.1014026108

154. Delarue M, Hartung J, Schreck C, Gniewek P, Hu L, Herminghaus $S$, Hallatschek O (2016). Self-Driven Jamming in Growing Microbial Populations. Nat Phys 12(8): 762-766. doi: 10.1038/nphys3741

155. Kruckeberg AL, Nagarajan S, McInnerney K, Rosenzweig F (2009). Extraction of RNA from Ca-Alginate Encapsulated Yeast for Transcriptional Profiling. Anal Biochem 391(2): 160-162. doi: 10.1016/j.ab.2009.04.032

156. Maršíková J, Wilkinson D, Hlaváček O, Gilfillan GD, Mizeranschi A, Hughes T, Begany $M$, Rešetárová S, Váchová L, Palková Z (2017). Metabolic differentiation of surface and invasive cells of yeast colony biofilms revealed by gene expression profiling. BMC Genomics 18: 814. doi: 10.1186/s12864-017-4214-4

157. Sobering AK, Jung US, Lee KS, Levin DE (2002). Yeast Rpi1 Is a Putative Transcriptional Regulator That Contributes to Preparation for Stationary Phase. Eukar Cell 1(1): 56-65. doi: 10.1128/EC.1.1.5665.2002

158. Tsang F, Lin S-J (2015). Less is more: Nutrient limitation induces cross-talk of nutrient sensing pathways with $\mathrm{NAD}(+)$ homeostasis and contributes to longevity. Front Biol 10(4): 333-357. doi: 10.1007/s11515-015-1367-x

159. Fabrizio P, Pozza F, Pletcher SD, Gendron CM, Longo VD (2001). Regulation of longevity and stress resistance by Sch9 in yeast. Science 292(5515): 288-290. doi: 10.1126/science.1059497

160. Bisschops MM, Zwartjens P, Keuter SG, Pronk JT, Daran-Lapujade $P$ (2014). To divide or not to divide: a key role of Rim15 in calorierestricted yeast cultures. Biochim Biophys Acta 1843(5): 1020-1030. doi: 10.1016/j.bbamcr.2014.01.026

161. Mai B, Breeden L (1997). Xbp1, a stress-induced transcriptional repressor of the Saccharomyces cerevisiae Swi4/Mbp1 family. Mol Cell Biol 17(11): 6491-6501. doi: 10.1128/mcb.17.11.6491

162. Miles S, Li L, Davison J, Breeden LL (2013). Xbp1 directs global repression of budding yeast transcription during the transition to quiescence and is important for the longevity and reversibility of the 
quiescent state. PLoS Genet 9(10): e1003854. doi: 10.1371/journal.pgen.1003854

163. Zegerman P, Diffley JFX (2009). DNA replication as a target of the DNA damage checkpoint. DNA Repair 8(9): 1077-1088. doi: 10.1016/j.dnarep.2009.04.023

164. Neganova I, Lako M (2008). G1 to S phase cell cycle transition in somatic and embryonic stem cells. J Anat 213(1): 30-44. doi 10.1111/j.1469-7580.2008.00931.x

165. Teng X, Hardwick JM (2013). Quantification of genetically controlled cell death in budding yeast. Methods Mol Biol 1004: 161-70. doi: 10.1007/978-1-62703-383-1_12

166. Pardee $A B$ (1974). A restriction point for control of normal animal cell proliferation. Proc Natl Acad Sci U S A 71(4): 1286-1290. doi: 10.1073/pnas.71.4.1286

167. Coller HA (2007). What's taking so long? S-phase entry from quiescence versus proliferation. Nat Rev Mol Cell Biol 8(8): 667-670. doi: $10.1038 / \mathrm{nrm} 2223$

168. Spencer SL, Cappell SD, Tsai FC, Overton KW, Wang CL, Meyer T (2013). The proliferation-quiescence decision is controlled by a bifur- cation in CDK2 activity at mitotic exit. Cell 155(2): 369-383. doi: 10.1016/j.cell.2013.08.062

169. Magrassi L, Leto K, Rossi $F$ (2013). Lifespan of neurons is uncoupled from organismal lifespan. Proc Natl Acad Sci U S A 110(11): 4374 4379. doi: 10.1073/pnas.1217505110

170. Petralia RS, Mattson MP, Yao PJ (2014). Aging and longevity in the simplest animals and the quest for immortality. Ageing Res Rev 16: 66-82. doi: 10.1016/j.arr.2014.05.003

171. Lemons JM, Feng XJ, Bennett BD, Legesse-Miller A, Johnson EL, Raitman I, Pollina EA, Rabitz HA, Rabinowitz JD, Coller HA (2010). Quiescent fibroblasts exhibit high metabolic activity. PLoS Biol 8(10): e1000514. doi: 10.1371/journal.pbio.1000514

172. Rosebrock AP, Caudy AA (2017). Metabolite Extraction from Saccharomyces cerevisiae for Liquid Chromatography-Mass Spectrometry. Cold Spring Harb Protoc 2017(9): pdb.prot089086. doi: 10.1101/pdb.prot089086 